Review

\title{
Development of Carbon Dioxide Barriers to Deter Invasive Fishes: Insights and Lessons Learned from Bigheaded Carp
}

\author{
Cory D. Suski \\ Department of Natural Resources and Environmental Sciences, University of Illinois, 1102 S Goodwin Ave, \\ Urbana, IL 61801, USA; suski@illinois.edu; Tel.: +1-217-244-2237
}

Received: 2 June 2020; Accepted: 4 August 2020; Published: 13 August 2020

\begin{abstract}
Invasive species are a threat to biodiversity in freshwater. Removing an aquatic invasive species following arrival is almost impossible, and preventing introduction is a more viable management option. Bigheaded carp are an invasive fish spreading throughout the Midwestern United States and are threatening to enter the Great Lakes. This review outlines the development of carbon dioxide gas $\left(\mathrm{CO}_{2}\right)$ as a non-physical barrier that can be used to deter the movement of fish and prevent further spread. Carbon dioxide gas could be used as a deterrent either to cause avoidance (i.e., fish swim away from zones of high $\mathrm{CO}_{2}$ ), or by inducing equilibrium loss due to the anesthetic properties of $\mathrm{CO}_{2}$ (i.e., tolerance). The development of $\mathrm{CO}_{2}$ as a fish deterrent started with controlled laboratory experiments demonstrating stress and avoidance, and then progressed to larger field applications demonstrating avoidance at scales that approach real-world scenarios. In addition, factors that influence the effectiveness of $\mathrm{CO}_{2}$ as a fish barrier are discussed, outlining conditions that could make $\mathrm{CO}_{2}$ less effective in the field; these factors that influence efficacy would be of interest to managers using $\mathrm{CO}_{2}$ to target other fish species, or those using other non-physical barriers for fish.
\end{abstract}

Keywords: invasive species; bigheaded carp; biodiversity; behavior; physiology; toxicity; avoidance

\section{Background}

The transport of species beyond their native range represents a major global problem. The arrival of an invasive species can lead to the suppression of native populations through competition, the introduction of pathogens, predation, hybridization, and disruptions to habitats and ecosystem function [1-3]. Invasive species are therefore believed to be the second most important driver of species extinctions after habitat loss [4], and can lead to billions of dollars in economic costs $[1,5]$. More importantly, the decrease in biodiversity that invasive species cause can threaten human health and well-being [1,6-8]. Freshwater environments are experiencing declines in biodiversity disproportionately large relative to other biomes $[9,10]$, and invasive species are one reason for this decline $[1,11]$. Studies have suggested that almost $40 \%$ of North American freshwater and diadromous fishes are imperiled [12], and the pace at which freshwater fish are becoming imperiled exceeds other vertebrates, and appears to be accelerating [12,13]; invasive species are a key factor contributing to these declines $[4,12]$. The rate at which humans have been introducing species beyond their native ranges has also accelerated over the past hundred years, driven primarily by the growth in global trade and mobility [3,14]. More importantly, models suggest that the transport of invasive species around the planet is likely to increase in the future $[15,16]$.

While the eradication of an invasive species is theoretically possible, the unfortunate reality is that, once a species is introduced into an area, its removal is often impossible. For an invasive species to be successfully eradicated, a number of conditions must be met. These conditions include: 
proper planning and establishing lines of authority, a commitment to complete the eradication effort in terms of resources and enthusiasm, the biology of the target species must be amenable with the entire population of the target species put at risk, the target population must be removed faster than it can reproduce, the target species must be detectable at low densities, and efforts must be made to prevent re-invasion (possibly through restoration activities) $[17,18]$. These conditions are easiest to meet for isolated, small populations with low reproductive rates and poor dispersal capabilities, often for terrestrial vertebrates, with plants and aquatic species proving more challenging $[17,18]$. Thus, owing to the challenges associated with eradication efforts, the literature is rich with examples of failed attempts to extirpate invasive species, despite efforts that have extended over many years [18-20]. In some situations, the goal of completely removing an invasive species can be considered controversial as eradication can be costly, unlikely to succeed, and may result in considerable damage to non-target organisms and the environment $[17,18,20]$. Owing to the obstacles associated with eradication, a common outcome following the invasion of a species is "maintenance management", whereby the goal of elimination is abandoned, and the invader is simply controlled to a density that is deemed tolerable and allowed to persist $[18,19]$. Therefore, to avoid this sustained presence of an invasive species and perpetual "maintenance management", a more cost-effective, and meaningful approach to invasive species management is to prevent the arrival of an invasive species prior to invasion $[1,21,22]$, or deter the secondary spread of invaders should they arrive [23].

\section{Bigheaded Carp}

Carps from the family Cyprinidae have been introduced outside of their native range for centuries. Bigheaded carps [24], and particularly bighead carp (Hypophthalmichthys nobilis) and silver carp (H. molitrix), have been introduced widely as phytoplankton control organisms in commercial aquaculture ponds and sewage lagoons owing to their large size and ability to efficiently filter phytoplankton and zooplankton from the water column [25]. Following transport to the United States for use as a biological control agent, floods allowed bigheaded carp to escape into the Mississippi River where they have spread throughout the basin [25], undeterred by locks, dams or other flood control structures [26], and are currently one of the most abundant species in portions of the Illinois River [27]. More importantly, bigheaded carp have had documented negative impacts on aquatic ecosystems [25]. Silver carp, for example, can consume detritus and bacteria [28], and reduce the size and abundance of both phytoplankton and zooplankton [25,27,29-31]. As a result, studies have shown that populations of bigheaded carps can result in reduced condition and abundance of native planktivorous fishes [32,33], as well as a reduction in the abundance of adult sport fish that compete with bigheaded carps at the larval and juvenile stages [34]. Owing to their abundance, mobility and impacts on receiving ecosystems, a tremendous amount of resources have been devoted to the suppression, removal and eradication of bigheaded carp from the Illinois River for almost a decade [35]. While efforts to date have been successful at reducing population sizes by removing millions of kilograms of fish through contract harvesting and agency collections [35], populations of bigheaded carp still remain throughout the Illinois River, necessitating suppression efforts to prevent the expansion of the population.

\section{Chicago Area Waterway System}

Bigheaded carp have direct access into the Great Lakes Basin from the Mississippi Basin due to the presence of the Chicago Area Waterway System (CAWS). The CAWS is a series of human-created canals and channels, completed in the early 1900s, that breached the continental divide between the two basins. The CAWS was constructed for the purpose of removing both sewage effluent and stormwater runoff from Chicago, coupled with allowing the passage of commercial shipping vessels to move from the Great Lakes to the Gulf of Mexico [36-38]. At present, the only means of deterring the movement of bigheaded carp through the CAWS from the Mississippi basin into the Great Lakes (beyond extensive suppression/harvest efforts) is a trio of electric barriers near Romeoville, IL, USA, constructed in 2002 [37]. Silver carp and bighead carp currently are over $60 \mathrm{~km}$ from Lake 
Michigan [39], so the effectiveness of these electric barriers at stopping bigheaded carp from passing has not been tested explicitly. However, numerous investigations have documented that these barriers are subject to problems and deficiencies that could allow the passage of bigheaded carp. For example, Dettmers et al. [40] showed that a number of fish confined to cages did not become immobilized when dragged through the barrier alongside steel-hulled barges, Sparks et al. [41] showed that an adult common carp (Cyprinus carpio) outfitted with an acoustic telemetry tag was able to traverse the electric barrier (possibly associated with a passing barge), while Evans and Brouder [42] showed that fish can move through the electric barriers if they are trapped between barges. Parker et al. [43] used stationary sonar deployed within the barriers and showed small fish were able to move through the electric fields independent of the presence of barges. In addition, electricity loses effectiveness when applied to small fish [44], the electric barrier is prone to maintenance shut downs, floods and power loss [38], and no non-physical barrier is effective at stopping 100\% of fish [45]. Mitigation measures have been proposed to redesign shipping locks to reduce the possibility of the exchange of invasive species between the Mississippi and the Great Lakes basins. The plan to modify locks will cost billions of dollars, take a decade or more to complete, and has yet to start, leaving the Great Lakes vulnerable to the passage of bigheaded carp through the CAWS for the foreseeable future [46]. The consequences, should bigheaded carps traverse the electric barriers and enter the Great Lakes, are not known and are difficult to predict [47-51]. The consensus is that an invasion of bigheaded carps would not be beneficial, however, making the containment of carp within the Mississippi Basin a critical priority for stakeholders. To supplement existing suppression efforts and increase redundancy and effectiveness at preventing movement or spread through the CAWS, additional barrier technologies would be valuable, ideally a technology that will permit the passage of barges and the downstream transport of wastewater through the CAWS.

Based on the above background, the goals of this review are to (1) outline the development of zones of carbon dioxide gas $\left(\mathrm{CO}_{2}\right)$ as a non-physical barrier to deter the movement of invasive fishes, with a particular focus on two bigheaded carps: silver carp and bighead carp, and (2) highlight internal and external factors that mediate the performance of $\mathrm{CO}_{2}$ as a non-physical barrier, either increasing or decreasing its effectiveness as a barrier for invasive fish passage. When taken together, this review will not only share the origins of $\mathrm{CO}_{2}$ as a fish barrier, but also help researchers think about ways to improve performance and maximize the ability of different barrier technologies to deter the spread of invasive fishes.

\section{Carbon Dioxide in the Atmosphere}

The idea that $\mathrm{CO}_{2}$ could be used as a fish barrier is rooted in Earth's history and the evolution of fishes. Billions of years ago, $\mathrm{CO}_{2}$ levels in the Earth's atmosphere were high, and $\mathrm{O}_{2}$ was low [52]. As photosynthesizing bacteria on the planet became more abundant, the composition of gasses in the atmosphere changed such that the relative level of $\mathrm{O}_{2}$ increased and the level of $\mathrm{CO}_{2}$ declined $[52,53]$. This change in atmospheric oxygen was concurrent with metabolic evolution that increased reliance on oxidative phosphorylation that uses oxygen as a final electron acceptor resulting in more efficient metabolism, coupled with the production of $\mathrm{CO}_{2}$ as a waste product [52]. Thus, organisms developed the ability to sense environmental gasses, including $\mathrm{CO}_{2}$, and respond by either avoiding $\mathrm{CO}_{2}$-rich areas that might impair energetic processes, or possibly being drawn to $\mathrm{CO}_{2}$-rich areas if they provide an energetic advantage [53]. Bacterial and fungal pathogens, for example, can sense environmental $\mathrm{CO}_{2}$ associated with hosts and alter growth or life cycles to maximize virulence [53]. Hawkmoths (Manduca sexta, Lepidoptera: Sphingidae) use floral $\mathrm{CO}_{2}$ emissions to quantify food source profitability and the amount of nectar in flowers [54], while honey bees (Apis mallifera) actively fan their hives to remove $\mathrm{CO}_{2}$ wastes, and the number of individuals fanning correlates positively with $\mathrm{CO}_{2}$ levels inside the colony [55]. Carbon dioxide excreted by vertebrates is used by mosquitoes (Aedes spp.) as a signal of a potential host [56,57], while Drosophila will avoid $\mathrm{CO}_{2}$, likely as a signal that rotting fruit is a poor food source [58]. For many terrestrial vertebrates, $\mathrm{CO}_{2}$ is detected by chemoreceptors in 
the blood stream and brain stem to regulate breathing [59], while, more specifically, mammals detect of $\mathrm{CO}_{2}$ in the air with free nerve endings of the trigeminal system [60]. Together, concentrations of environmental $\mathrm{CO}_{2}$ can be a source of ecologically relevant information, and the ability to detect and respond to $\mathrm{CO}_{2}$ as a stimulus has persisted across kingdoms.

\section{5. $\mathrm{CO}_{2}$ and Fish Physiology}

Carbon dioxide has a pronounced effect on fishes, resulting in a host of physiological and behavioral responses when concentrations above species-specific set-points are experienced. Fish predominantly sense ambient $\mathrm{CO}_{2}$ using peripheral chemoreceptors, largely in the gills, that respond to $\mathrm{CO}_{2}$ tension in the water, not changes in $\mathrm{pH}$; some evidence does exist for the presence of internal $\mathrm{CO}_{2}$ sensors, but the location of these sensors has not been well-defined [61]. When fish are placed in a high carbon dioxide environment, $\mathrm{CO}_{2}$ passively diffuses into the fish down its concentration gradient, and arterial $\mathrm{CO}_{2}$ equilibrates with environmental $\mathrm{CO}_{2}$ within minutes, resulting in an internal acidosis $[62,63]$. Over time, this $\mathrm{pH}$ imbalance is corrected as fish uptake $\mathrm{HCO}_{3}{ }^{-}$from the environment (in exchange for $\mathrm{Cl}^{-}$) and excrete $\mathrm{H}^{+}$(in exchange for $\mathrm{Na}^{+}$) [63]. Owing to this influx of $\mathrm{CO}_{2}$, hypercarbic environments cause an elevation of the general stress response [64-66], a drop in blood $\mathrm{pH}$ [67], a loss of ions [68], and, ultimately, equilibrium loss and anesthesia (Stage 2 or Stage 3) $[64,67,69,70]$. At present, the exact mechanism(s) responsible for the loss of equilibrium and the anesthetic impacts of carbon dioxide have not been well defined, but are believed to result from the movement of $\mathrm{CO}_{2}$ across the blood-brain barrier, which alters brain $\mathrm{pH}$ and an impairs brain electrical activity [71,72]; additions $\mathrm{of}^{+}$or $\mathrm{HCO}_{3}{ }^{-}$alone will not result in anesthesia for fish [71]. In addition to these physiological changes, studies have documented behavioral changes exhibited by fish in high $\mathrm{CO}_{2}$ environments including hyperventilation, coupled with a reduction in heart rate, likely to facilitate $\mathrm{CO}_{2}$ excretion [61]. Together, exposure to water with elevated concentrations of $\mathrm{CO}_{2}$ has been shown to result in both physiological and behavioral changes to fish.

\section{6. $\mathrm{CO}_{2}$ and Fish Behavior}

A number of past studies have highlighted the propensity for fish to voluntarily swim away from areas of high carbon dioxide, laying the foundation for the use of $\mathrm{CO}_{2}$ as a fish deterrent. Avoidance reactions are considered the first line of defense for fish that encounter adverse stimuli, and poor water quality can quickly induce a behavioral response that causes fish to depart an area and seek out improved water, presumably to minimize energetic costs [73,74] (Figure 1).

Over a century ago, Shelford and Allee [75] designed a simple experiment to observe the behavior of nine fish species when placed individually in a raceway containing a gradient of $\mathrm{CO}_{2}$, ranging from approximately 2-88 cubic centimeters of $\mathrm{CO}_{2}$ per liter of water. Shelford and Allee [75] showed that, upon entering zones of elevated $\mathrm{CO}_{2}$, some fish started surface ventilations, while others displayed a coughing or yawning reaction coupled with increased ventilation rates. In addition, Shelford and Allee [75] reported that some fish would enter the area of high $\mathrm{CO}_{2}$, stop suddenly, and then move backwards as if they had "encountered a sheet-rubber wall", and all fish spent less time in areas of high $\mathrm{CO}_{2}$ relative to areas with lower $\mathrm{CO}_{2}$. Powers and Clark [76] used a laboratory gradient tank design similar to Shelford and Allee [75] and showed that both brook trout (Salvelinusf. frontinalis) and rainbow trout (Salmo gairdnerii iridus) also avoided water that had received "very slight" additions of $\mathrm{CO}_{2}$ (a drop of approximately $0.4 \mathrm{pH}$ units). This pattern was also confirmed by Collins [77] who showed that individual alewife (Polumbus pseudoharengus) and glut herring (P. aestivalis) (likely river herring) migrating upriver both avoided water with elevated $\mathrm{CO}_{2}$ that exceeded $0.3 \mathrm{ppm}$, independent of $\mathrm{pH}$ changes. Bishai [78] showed that juvenile brown trout (Salmo trutta) and Atlantic salmon (Salmo salar) demonstrated a stronger avoidance response to a $\mathrm{pH}$ change caused by $\mathrm{CO}_{2}$ relative to a $\mathrm{pH}$ change caused by hydrochloric acid. Jones et al. [79] noted that individual arctic char (Salvelinus aplinus) will avoid concentrations of $\mathrm{CO}_{2}$ that exceed $50 \mu \mathrm{mol} / \mathrm{L}$, Ross et al. [80] showed that brook trout and blacknose dace (Rhinichthys atratulus) would avoid water with $\geq 2 \% \mathrm{CO}_{2}$, while Clingerman et al. [81] 
reported that intentional elevations of $\mathrm{CO}_{2}$ to $60 \mathrm{mg} / \mathrm{L}$ in an aquaculture would induce avoidance behavior in groups of rainbow trout (Oncorhynchus mykiss), thereby facilitating harvest and collection in recirculating tanks. Finally, both Bernier and Randall [64], as well as Yoshikawa [82], revealed that rainbow trout exhibited a "violent" struggle upon being exposed to water maintained at $36-350 \mathrm{mmHg}$ $\mathrm{CO}_{2}$, while Clingerman et al. [81] indicated that rainbow trout in aquaculture tanks demonstrated "chaotic" swimming when $\mathrm{CO}_{2}$ levels were increased to $35-60 \mathrm{mg} / \mathrm{L}$. Thus, for over 100 years, studies have documented that many fish species will avoid areas of elevated $\mathrm{CO}_{2}$ once a threshold is reached, providing the proof of concept that $\mathrm{CO}_{2}$ could be a potential non-physical barrier for invasive fishes.

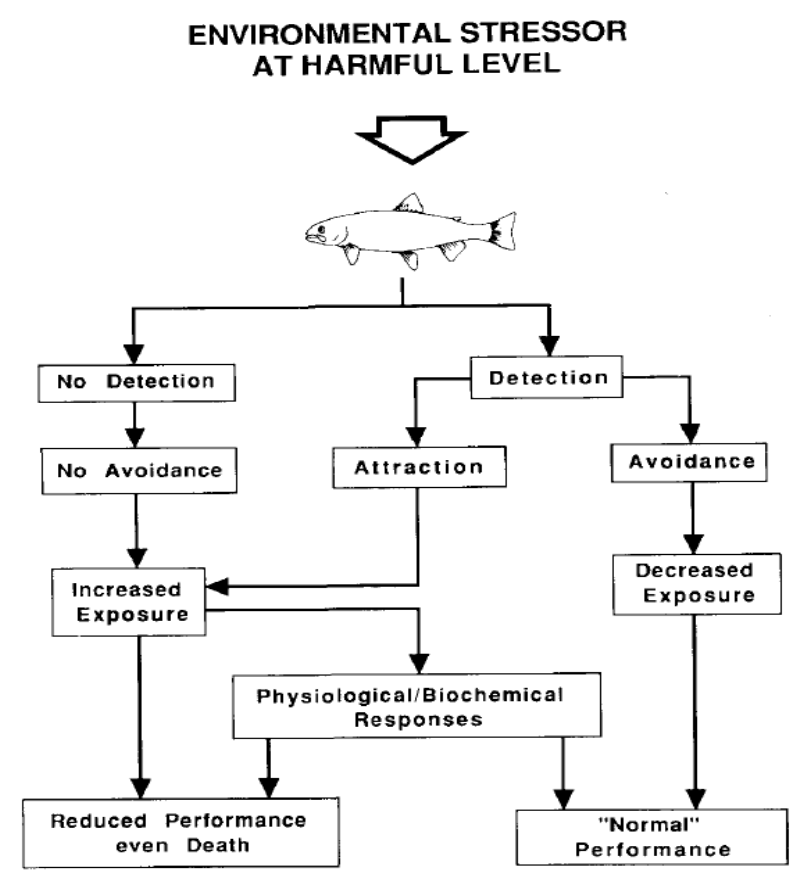

Figure 1. Flow chart showing the possible reactions of fishes to a potentially adverse environmental stimulus, such as an area of elevated carbon dioxide [73].

Despite suggestions from past work that $\mathrm{CO}_{2}$ could induce avoidance behaviors and act a barrier to the movement of bigheaded carp, a key unknown was the threshold $\mathrm{CO}_{2}$ level that should be targeted to induce avoidance. While the response of fishes to high concentrations of $\mathrm{CO}_{2}$ when applied as an anesthetic appeared to be consistent $[67,83]$, and the physiological responses of fishes to general hypercarbia had been well-defined [63], relatively less was known about the thresholds or "inflection points" that cause the onset of disturbances (i.e., a dose-response curve), and if those threshold concentrations were consistent across species and life stages. For example, Ross et al. [80] exposed book trout, slimy sculpin (Cottus cognatus) and blacknose dace to four levels of $\mathrm{CO}_{2}(0 \%$, $1.4 \%, 2.8 \%$ and $5.1 \%$ ) for either one or $24 \mathrm{~h}$ and noted differences in physiological responses both across species and across exposure durations, suggesting species-specific responses to $\mathrm{CO}_{2}$ exposure. To address this need and define concentrations that induced onset of disturbances, Kates et al. [66] exposed bluegill (Lepomis macrochirus), largemouth bass (Micropterus salmoides), silver carp (>450 mm) and bighead carp (>700 mm) to two different concentrations of $\mathrm{CO}_{2}(30 \mathrm{mg} / \mathrm{L}$ and $70 \mathrm{mg} / \mathrm{L})$ for three hours and showed that, $30 \mathrm{mg} / \mathrm{L} \mathrm{CO}_{2}$ (approximately $2000 \mu \mathrm{atm} \mathrm{CO}_{2}$ ) had minimal physiological or behavioral impacts, but a three hour exposure to $70 \mathrm{mg} / \mathrm{L} \mathrm{CO}_{2}$ (approximately 50,000 $\mu$ atm $\mathrm{CO}_{2}$ ) resulted in a drop in ventilation rates, and an increase in irregular behaviors such as erratic swimming, twitching and escape attempts for silver carp and bighead carp [66]. One of the challenges with the study by Kates et al. [66], however, was that adult bigheaded carp were used, which provided little evidence in support of how small fish, those presumably less vulnerable to the existing electric barriers in Romeoville, IL, would respond to $\mathrm{CO}_{2}$. In an effort to better define the allometric response of 
fish to $\mathrm{CO}_{2}$ exposure, Dennis et al. [84] exposed larval and juvenile $(73 \mathrm{~mm})$ silver carp and bighead carp to $120 \mathrm{mg} / \mathrm{L} \mathrm{CO}_{2}$ (approximately $42,000 \mu$ atm $\mathrm{CO}_{2}$ ) for 30 and $60 \mathrm{~min}$. Results from this study were similar to previous work with adult fish, in that exposing larval silver carp and bighead carp to $42,000 \mu \mathrm{atm} \mathrm{CO}_{2}$ for $30 \mathrm{~min}$ resulted in an increase in the mRNA coding for genes associated with the stress response (Hsp70 and c-fos) [84] (Figure 2).
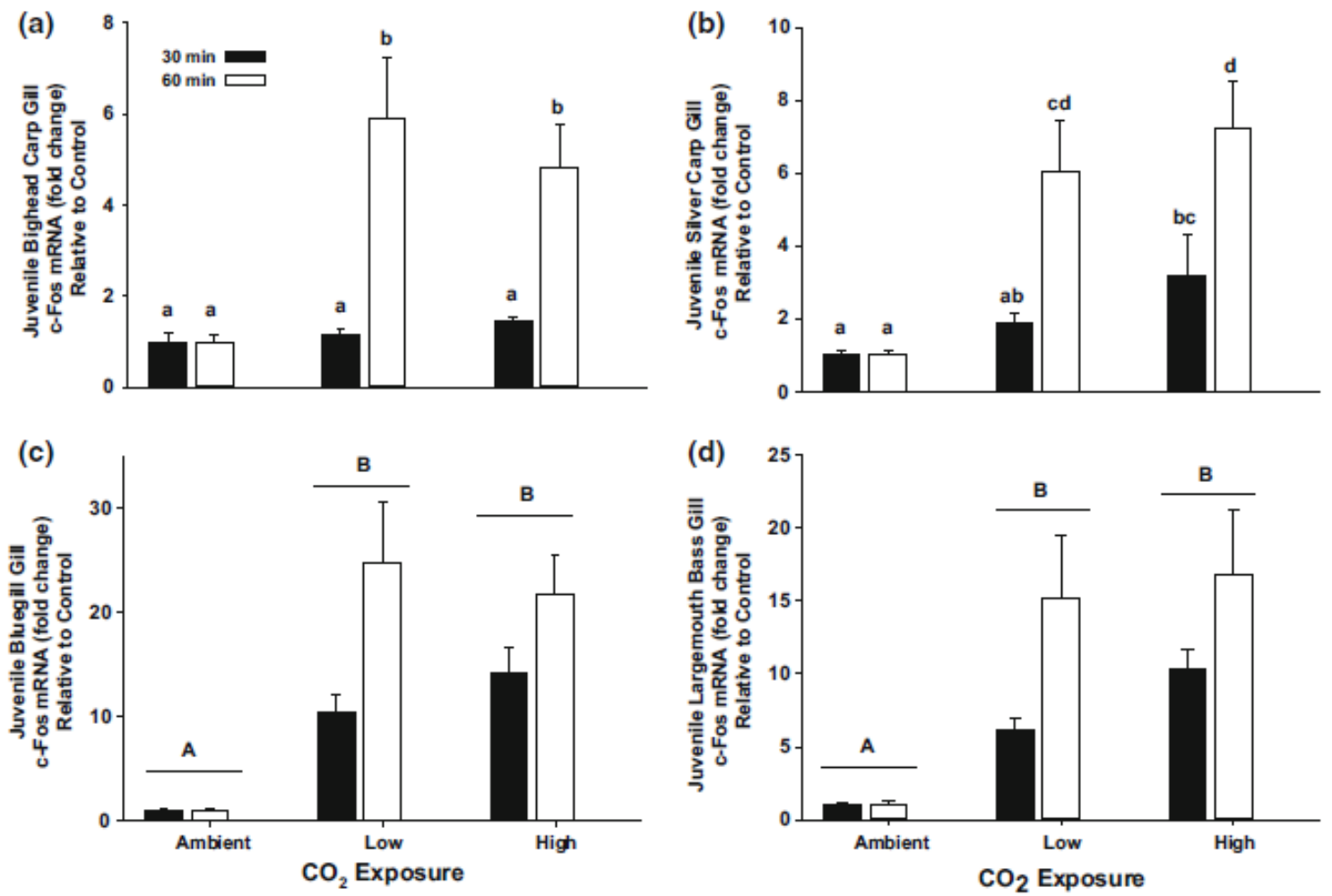

Figure 2. Relative expression of c-fos mRNA extracted from the gill tissue of juvenile bighead carp (a), silver carp (b), bluegill (c), and largemouth bass (d) exposed to a two hypercarbic treatments. Relative mRNA expression of juvenile fish that had an exposure duration of $30 \mathrm{~min}$ are shown in black bars, while white bars show the mRNA expression of juvenile fish exposed for $60 \mathrm{~min}$. Horizontal lines denote a significant $\mathrm{CO}_{2}$ concentration effect across exposure durations within a species. Dissimilar letters indicate significant differences between bars within a species. Data are mean $\pm \mathrm{SE}$, calculated relative to the expression of the reference gene (i.e., either $18 \mathrm{~s}$ or ef1-a). For clarity, data are expressed relative to the mean of juvenile fish exposed to ambient water conditions [84].

Thus, when results from these two studies are taken together, data suggest that thresholds of approximately $42,000 \mu \mathrm{atm} \mathrm{CO}_{2}(70-120 \mathrm{mg} / \mathrm{L})$ induce a suite of physiological and behavioral responses for a range of sizes of silver and bighead carp consistent with stress or discomfort, providing a target in the development of a non-physical barrier for fish.

\section{7. $\mathrm{CO}_{2}$ and Physiological Responses}

Following the identification of putative thresholds that would induce behavioral and physiological disturbances, studies on $\mathrm{CO}_{2}$ barriers shifted to quantify aspects of avoidance (Figure 1). Despite the research mentioned above that indicated a pattern of fish avoiding zones of elevated $\mathrm{CO}_{2}$, there were suggestions in the literature that avoidance responses may be variable across species. Ross et al. [80], for example, showed that individual slimy sculpin did not avoid zones of elevated $\mathrm{CO}_{2}$ and preferred to rest in place when confronted with hypercarbia, while Summerfelt and Lewis [85] noted that $\mathrm{CO}_{2}$ concentrations from $3.0-9.7 \mathrm{mg} / \mathrm{L}$ did not repel green sunfish (Lepomis cyanellus) in a graded laboratory tank. Early work with $\mathrm{CO}_{2}$ avoidance and bigheaded carp was conducted by Kates et al. [66] who used 
a "shuttle-box" apparatus in a laboratory to show that individual adult silver carp (460 mm) would voluntarily swim away from $\mathrm{CO}_{2}$ once concentrations were elevated to approximately $120 \mathrm{mg} / \mathrm{LCO}_{2}$, although there was considerable variation around this mean value (Figure 3) (Table 1).

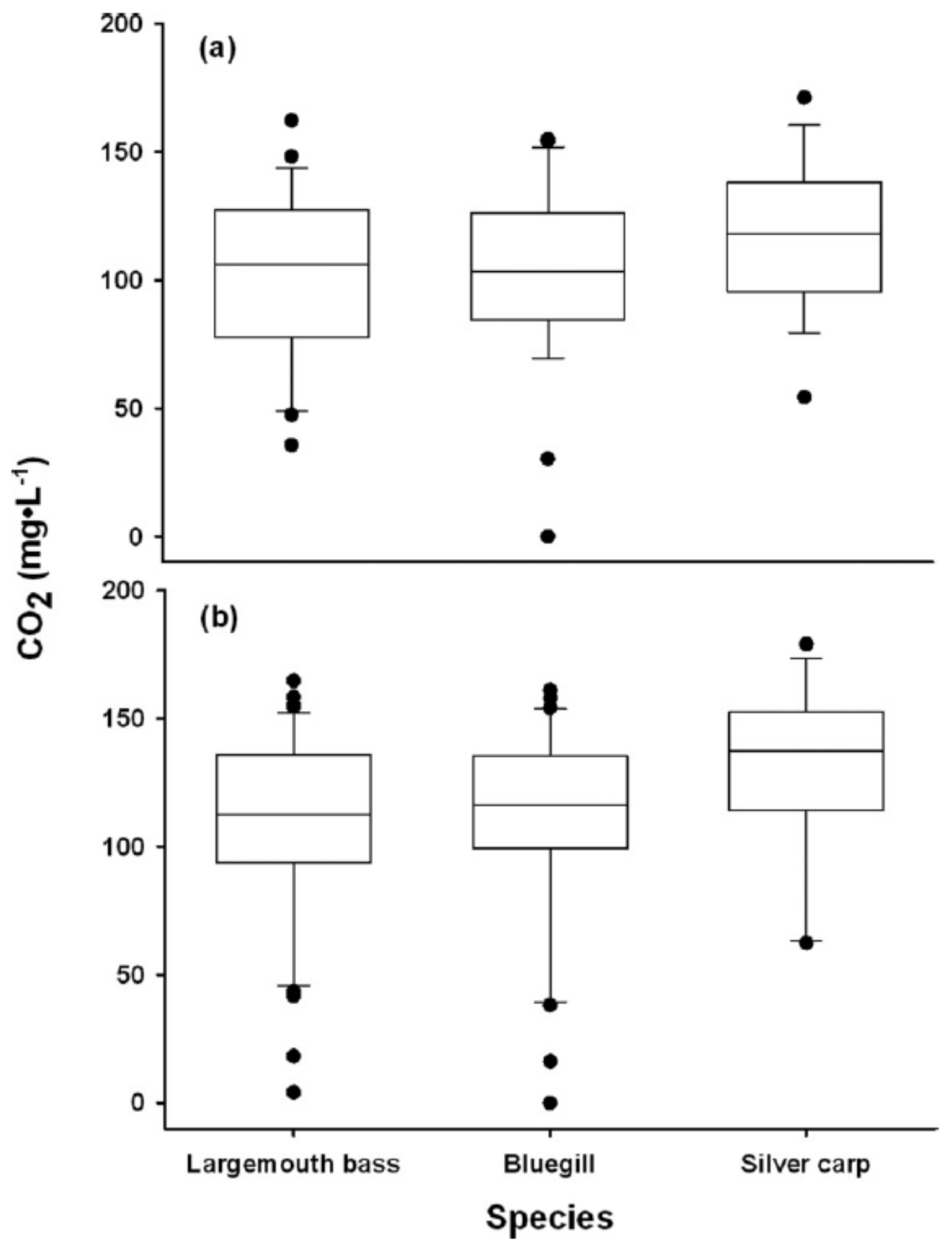

Figure 3. Concentration of $\mathrm{CO}_{2}$ at which largemouth bass, bluegill, and silver carp displayed either an agitated activity (surface ventilations, twitching, or elevated swimming activity) (a) or movement out of high $\mathrm{CO}_{2}$ environment to a lower $\mathrm{CO}_{2}$ environment (b) during the course of avoidance trials [66].

Dennis et al. [84] later used juvenile silver carp and bighead carp (67 $\mathrm{mm}$ and $71 \mathrm{~mm}$, respectively) and the shuttle-box apparatus, and, again, showed that individual fish would voluntarily swim away from zones of elevated $\mathrm{CO}_{2}$. The concentration of $\mathrm{CO}_{2}$ required to induce avoidance in this series of tests averaged approximately $180-220 \mathrm{mg} / \mathrm{L} \mathrm{CO}_{2}$, and, again, the variance around the mean was considerable (Figure 4). The success of these laboratory trials led to work at larger settings, including 
Donaldson et al. [86] who showed that a number of fish species, including silver carp and bigheaded carp, released into a $4000 \mathrm{~m}^{3}$ outdoor pond in groups of 5-10 avoided zones of elevated $\mathrm{CO}_{2}$ elevated to approximately $30,000 \mu \mathrm{atm}(60 \mathrm{mg} / \mathrm{L})$, and Cupp et al. [87] who used a two-channel, outdoor raceway (approximately $60 \mathrm{~m}^{3}$ ) with flowing water and showed that $\mathrm{CO}_{2}$ levels of approximately

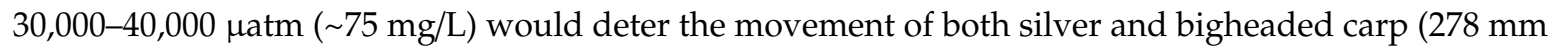
and $212 \mathrm{~mm}$, respectively) when tested in groups of 10 (Table 1). Cupp et al. [88] showed that $\mathrm{CO}_{2}$ deployed at the mouth of an outflow structure draining a backwater lake could reduce the abundance of shoals of mixed fish species by $70-95 \%$ at low water flows once a target threshold of $100 \mathrm{mg} / \mathrm{L}$ was reached. Finally, Hasler et al. [89] worked in a $12 \mathrm{~m}$ long indoor swim flume and showed that bighead carp $(145 \mathrm{~mm})$ in shoals of 3 would avoid $\mathrm{CO}_{2}$ in water flowing at approximately $15 \mathrm{~cm} / \mathrm{seconds}$ (equivalent to 1 body length per second), and $\mathrm{CO}_{2}$ levels in this study were approximately 190,000 $\mu \mathrm{atm}$. When considered together, these studies used a number of environments (indoor, outdoor, static water, flowing water) to demonstrate that a range of sizes of invasive silver and bighead carp, including small fish presumed to be less vulnerable to electricity, would voluntarily swim away from zones of elevated $\mathrm{CO}_{2}$ once a threshold of approximately $70,000 \mu \mathrm{atm}(100 \mathrm{mg} / \mathrm{L})$ was reached, providing support for the use of $\mathrm{CO}_{2}$ as a non-physical barrier.

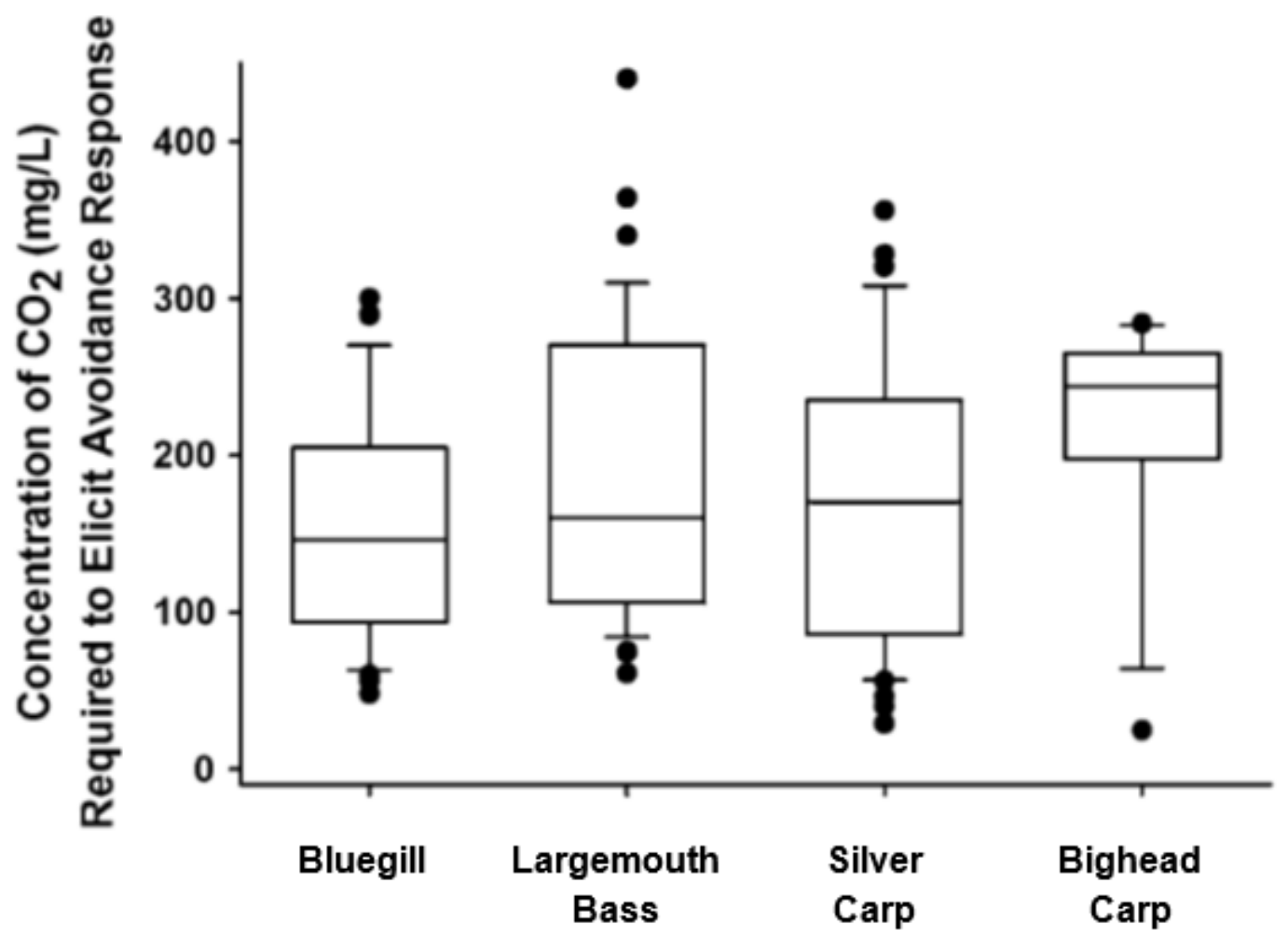

Figure 4. Concentration of $\mathrm{CO}_{2}$ at which juvenile bluegill, largemouth bass, silver carp and bighead carp displayed avoidance behaviors [84]. 
Table 1. Summary of studies quantifying $\mathrm{CO}_{2}$ thresholds that caused avoidance within the framework of generating a non-physical barrier for silver carp and bighead carp. Data have been approximated from figures whe.2e it was not clearly outlined in text of the citation. Units are left in the format that was used during publication.

\begin{tabular}{|c|c|c|c|c|c|c|}
\hline Species & Avoidance Threshold & Test Environment & Temperature & $\mathrm{pH}$ & $\begin{array}{l}\text { Mean Fish } \\
\text { Size (mm) }\end{array}$ & Citation \\
\hline \multirow{4}{*}{ Silver carp } & $135 \mathrm{mg} / \mathrm{L}$ & Shuttle box & $18^{\circ} \mathrm{C}$ & 8.0 & 460 & [66] \\
\hline & $125 \mathrm{mg} / \mathrm{L}$ & Shuttle box & $16^{\circ} \mathrm{C}$ & 7.46 & 67 & [65] \\
\hline & 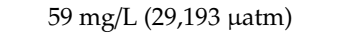 & Outdoor static pond & $16^{\circ} \mathrm{C}$ & 8.25 & 254 & [86] \\
\hline & $75 \mathrm{mg} / \mathrm{L}(29,532-41,393 \mu \mathrm{atm})$ & Outdoor flowing raceway & $8-13^{\circ} \mathrm{C}$ & 7.5 & 278 & [87] \\
\hline \multirow{4}{*}{ Bighead carp } & $180 \mathrm{mg} / \mathrm{L}$ & Shuttle box & $16^{\circ} \mathrm{C}$ & 7.46 & 71 & [65] \\
\hline & 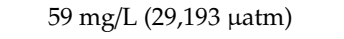 & Outdoor static pond & $16^{\circ} \mathrm{C}$ & 8.25 & 205 & [86] \\
\hline & $75 \mathrm{mg} / \mathrm{L}(29,532-41,393 \mu \mathrm{atm})$ & Outdoor flowing raceway & $8-13{ }^{\circ} \mathrm{C}$ & 7.5 & 212 & [87] \\
\hline & $160,000-186,000 \mu \mathrm{atm}$ & Indoor flowing raceway & $21^{\circ} \mathrm{C}$ & 8.3 & 145 & [89] \\
\hline
\end{tabular}

\section{8. $\mathrm{CO}_{2}$ as a Potential Fish Barrier}

When the general anesthetic properties of $\mathrm{CO}_{2}$ exposure [67] were combined with results from field and lab avoidance trials, there was a considerable amount of evidence to suggest that zones of elevated $\mathrm{CO}_{2}$ could deter the spread of invasive bigheaded carps. More specifically, a $\mathrm{CO}_{2}$ barrier could be deployed in one of two different ways. First, $\mathrm{CO}_{2}$ could be deployed as a "fence" or wall with the goal of inducing avoidance behaviors in fishes, exploiting the fact that fish voluntarily swim away from areas of high $\mathrm{CO}_{2}$ once a threshold had been reached. For example, $\mathrm{CO}_{2}$ could be used to confine carp in backwater areas [90] preventing access to turbulent, high-velocity water flowing river environments used for spawning [91], or at a choke-point in a river (e.g., shipping lock) to stop movement. $\mathrm{A} \mathrm{CO}_{2}$ barrier deployed in this way could be temporary (e.g., deployed only during summer or during harvest), or for longer periods of time. Secondly, zones of $\mathrm{CO}_{2}$ could be deployed to intentionally induce equilibrium loss for fish, taking advantage of the ability of fish to tolerate $\mathrm{CO}_{2}$ as an anesthetic. Again, an application of this kind could be temporary (i.e., deployed at specific times of the year) or longer-term (e.g., added to a shipping lock) [46].

\section{Questions from Avoidance Data}

While the concept of using $\mathrm{CO}_{2}$ as a barrier based on either avoidance or a tolerance has support from a number of studies, there were several puzzling trends in the data, which generated questions and presented challenges related to possible deployment. For example, shuttle-box work by Kates et al. [66] showed that avoidance thresholds for individual adult silver carp and bighead carp spanned from approximately $50 \mathrm{mg} / \mathrm{L}$ to $160 \mathrm{mg} / \mathrm{L}$ (Figure 3) (Table 1). Subsequent shuttle-box work by Dennis et al. [84] with juvenile fishes, showed that avoidance thresholds ranged 6-fold, from approximately $50-300 \mathrm{mg} / \mathrm{L}$ (Figure 4). This variation in avoidance is further complicated by work from outdoor ponds showing avoidance occurred for groups of bighead carp, but $\mathrm{CO}_{2}$ never exceed $60-75 \mathrm{mg} / \mathrm{L}[86,87]$. Questions therefore arose related to the source of this variation (i.e., Is there inter-individual variation? What is the nature of the differing test environments? Is this variation inherent in how animals respond to zones of $\mathrm{CO}_{2}$ ?), the potential for inter-individual differences in tolerance, and the effectiveness/consistency of $\mathrm{CO}_{2}$ across time periods or environments. Thus, it was difficult to make recommendations to managers on target thresholds necessary to achieve an effective $\mathrm{CO}_{2}$ barrier, or to predict possible changes in barrier effectiveness, without a more thorough understanding of the response of fish to $\mathrm{CO}_{2}$ barriers. A series of studies were therefore conducted to quantify endogenous and exogenous factors that influenced the avoidance and tolerance of fishes to elevated $\mathrm{CO}_{2}$ in hopes of refining this technology, providing stronger, more definitive recommendations to managers on target thresholds for $\mathrm{CO}_{2}$ barriers, and improving the likelihood of long-term performance of $\mathrm{CO}_{2}$ as a non-physical barrier. 


\section{Factors Influencing the Avoidance of $\mathrm{CO}_{2}$}

Several different endogenous and exogenous factors have the potential to influence the avoidance response of $\mathrm{CO}_{2}$ in the context of a non-physical barrier (Table 2). For instance, in recent years, it has become apparent that fish consistently differ from each other in behavior, often termed "personality"; some individuals are more bold than others, some are more active, and some are more likely to explore novel areas [92]. Invasive round goby at the leading edge of their range, for example, were shown to be more bold and willing to explore novel areas than individuals from established, core populations [93], and it is therefore plausible that individual differences in personality could be manifesting in inter-individual differences to $\mathrm{CO}_{2}$ avoidance [94] (Figures 3 and 4). More importantly, personality differences covary with characteristics such as the response to stressors, life span and growth rate through the pace-of-life continuum [92]. Therefore, if the response to an environmental stress and avoidance thresholds are mediated through behavior (e.g., proactive vs. reactive coping styles [92,95]), due to links between personality, life history and fitness [96], if target levels for an avoidance barrier are too low and fish of a particular behavioral type are able to pass, this could translate to population-level shifts in phenotypes, possibly changing avoidance thresholds for a population. In exploration of this concept, Tucker et al. [97] showed that aspects of personality (e.g., activity and boldness) did not influence $\mathrm{CO}_{2}$ avoidance in individual bluegill, with fish of all personality types avoiding $\mathrm{CO}_{2}$ at a threshold of approximately 67,000 $\mu \mathrm{atm}$. In addition, Tucker and Suski [98] showed that social personality in bluegill (e.g., sociability, clustering with conspecifics and conspecific aggression) also did not influence $\mathrm{CO}_{2}$ avoidance thresholds or the order that fish avoided $\mathrm{CO}_{2}$. Related to this, past work has shown that food deprivation can alter the behavior of fish through plastic or flexible changes, with animals deprived of food taking more risks and becoming more active, likely as they search for food [99,100]. Interestingly, Suski et al. [101] showed that nine days of food deprivation did not influence $\mathrm{CO}_{2}$ avoidance thresholds for individual largemouth bass; fish that had been fed and fish that had been deprived of food, both avoided high $\mathrm{CO}_{2}$ at thresholds of approximately 70,000 $\mu \mathrm{atm}$. However, Tucker et al. [97] showed that $\mathrm{CO}_{2}$ avoidance in individual largemouth bass was influenced by artificial activation of the stress axis as fish that received an intraperitoneal injection of cortisol (hydrocortisone 21-hemisuccinate) required $45 \%$ more $\mathrm{CO}_{2}$ to induce avoidance behavior relative to fish that did not receive an artificial elevation of the stress axis. Many initial studies of $\mathrm{CO}_{2}$ avoidance $[66,84]$ were conducted on individual fish, but shoals have a number of benefits for fish including predator vigilance and food detection, resulting in a calming effect and a reduced response to environmental stressors [102]. Tucker and Suski [98] showed pronounced differences in $\mathrm{CO}_{2}$ avoidance thresholds for individual fish relative to shoals, with groups of bluegill choosing to swim away from $\mathrm{CO}_{2}$ at significantly lower thresholds than individual bluegill; interestingly Tucker et al. [97] also showed that shuttling thresholds were not repeatable within individuals. Allometry is known to influence a number of characteristics of fish including metabolism and survival, but intraspecific differences in $\mathrm{CO}_{2}$ avoidance thresholds across size categories is not clear. When avoidance thresholds for small and large bighead carp are compared across Kates et al. [66] and Dennis et al. [103], small fish appear to require higher $\mathrm{CO}_{2}$ thresholds to induce avoidance. These results, however, were obtained in separate studies, not in a single investigation, so inter-study differences may have been a complicating factor. The quantity of $\mathrm{CO}_{2}$ necessary to induce avoidance in round goby (Neogobius melanostomus) [104], silver carp and bighead carp [105] correlated positively with water temperature (range from $5-25^{\circ} \mathrm{C}$ ), such that more $\mathrm{CO}_{2}$ was required to induce avoidance at high temperatures for all three species tested. Note that both Cupp et al. [104] and Tix et al. [105] did not acclimate fish at test temperatures for a period of two to three weeks as is common [106,107], with holding times listed at two to six days, which could have influenced these results. Together, a number of factors have been shown to influence the threshold of $\mathrm{CO}_{2}$ required to induce avoidance behaviors, which have implications for the application of $\mathrm{CO}_{2}$ as an avoidance barrier to deter the movement of invasive fishes (Table 2). 
Table 2. Factors influencing the thresholds of $\mathrm{CO}_{2}$ required to induce avoidance behaviors in fishes.

\begin{tabular}{|c|c|c|c|c|}
\hline & Factor & Outcome & Species & Citation \\
\hline \multirow{2}{*}{$\begin{array}{l}\text { Factors resulting in } \\
\text { more } \mathrm{CO}_{2} \text { needed } \\
\text { for avoidance }\end{array}$} & Temperature & $\begin{array}{l}\text { Higher concentrations of } \mathrm{CO}_{2} \\
\text { needed to induce avoidance at high } \\
\text { temperatures relative to } \\
\text { low temperatures. }\end{array}$ & $\begin{array}{l}\text { Bighead carp, } \\
\text { silver carp, } \\
\text { round goby }\end{array}$ & {$[104,105]$} \\
\hline & Stress & $\begin{array}{l}\text { Fish with artificially-elevated } \\
\text { cortisol levels required more } \mathrm{CO}_{2} \text { to } \\
\text { induce shuttling than } \\
\text { non-stressed controls. }\end{array}$ & $\begin{array}{l}\text { Largemouth } \\
\text { bass }\end{array}$ & [97] \\
\hline $\begin{array}{c}\text { Factors requiring } \\
\text { less } \mathrm{CO}_{2} \text { for } \\
\text { avoidance }\end{array}$ & Shoals & $\begin{array}{l}\text { Shoals of fish avoided } \mathrm{CO}_{2} \text { at lower } \\
\text { thresholds than did individual fish. }\end{array}$ & Bluegill & [97] \\
\hline \multirow{3}{*}{$\begin{array}{l}\text { Factors not } \\
\text { influencing } \mathrm{CO}_{2} \\
\text { avoidance }\end{array}$} & $\begin{array}{l}\text { Social } \\
\text { personality }\end{array}$ & $\begin{array}{l}\text { Preference for associating with } \\
\text { conspecifics did not influence } \\
\text { thresholds for } \mathrm{CO}_{2} \text { avoidance. }\end{array}$ & Bluegill & [97] \\
\hline & Personality & $\begin{array}{l}\text { Activity and boldness did not } \\
\text { influence } \mathrm{CO}_{2} \\
\text { avoidance thresholds. }\end{array}$ & Bluegill & [97] \\
\hline & Feeding & $\begin{array}{l}\text { Fish that had been deprived food } \\
\text { for } 9 \text { days avoided } \mathrm{CO}_{2} \text { at the same } \\
\text { threshold as fed conspecifics }\end{array}$ & $\begin{array}{l}\text { Largemouth } \\
\text { bass }\end{array}$ & [101] \\
\hline
\end{tabular}

\section{Factors Influencing $\mathrm{CO}_{2}$ Tolerance}

Similar to work with avoidance, a number of studies have been carried out to quantify inter-individual differences in $\mathrm{CO}_{2}$ tolerance, as well as potential mechanisms for any differences (Table 3). Importantly, Hasler et al. [108] showed that, for largemouth bass, $\mathrm{CO}_{2}$ tolerance not only varied across individuals, with some fish losing equilibrium in high $\mathrm{CO}_{2}$ sooner than others, but also that the individual response to high $\mathrm{CO}_{2}$ was repeatable within individuals, suggesting potential for this to be a heritable trait that can be acted upon by natural selection [109]. In general, tolerance to $\mathrm{CO}_{2}$ is a function of the interaction of exposure time $\times$ concentration, further mediated by temperature $[64,69,70,110-112]$. More specifically, a brief exposure to a high concentration of ambient $\mathrm{CO}_{2}$, or an extended exposure to lower concentrations of $\mathrm{CO}_{2}$, will both result in equilibrium loss, provided that the concentration of ambient $\mathrm{CO}_{2}$ is sufficient to passively diffuse into the bloodstream of the fish $[64,70,110,112]$. Owing to reduced respiratory and metabolic rates at low temperatures, fish typically require additional time at lower temperatures before anesthetic effects are realized relative to high temperatures [112]. Indeed, this has been demonstrated for $\mathrm{CO}_{2}$ as both Fish [69] and Gelwicks et al. [110] used study designs where individual fish were transferred to containers of $\mathrm{CO}_{2}$ at a target concentration and showed decreased time to equilibrium loss at high temperatures, suggesting that fish are more sensitive to $\mathrm{CO}_{2}$ at high temperatures. Interestingly, both Cupp et al. [104], and Tix et al. [105], showed that, when $\mathrm{CO}_{2}$ was continually added to a test tank, round gobies [104], silver carp and bighead carp [105] all required higher concentrations of $\mathrm{CO}_{2}$ before equilibrium loss occurred when animals were at high temperatures relative to low temperatures, suggesting that fish were more tolerant to $\mathrm{CO}_{2}$ at higher temperatures. There are three potential explanations for the discrepancies across these studies. Firstly, differences across studies could be due to experimental animals, as Fish [69] and Gelwicks et al. [110] worked with salmonids, while Tix et al. [104] and Cupp et al. [105] used round goby and bigheaded carp. Secondly, Tix et al. [105] and Cupp et al. [104] applied $\mathrm{CO}_{2}$ to fish continuously until equilibrium loss occurred, while Fish [69] and Gelwicks et al. [110] pre-treated tanks of water with $\mathrm{CO}_{2}$ to a set point and added fish. Finally, both Cupp et al. [104] and Tix et al. [105] did not acclimate animals to each test temperature for extended periods of time, and, rather, animals were first held at $12{ }^{\circ} \mathrm{C}$ and then transferred to the test temperatures for 24-144 h prior to testing, which may have influenced their response to $\mathrm{CO}_{2}$ 
exposure [106,107]. Clingerman [81] showed that, when $\mathrm{CO}_{2}$ level was held constant, large rainbow trout were more likely to lose equilibrium than small rainbow trout in aquaculture tanks, suggesting an increased tolerance for smaller fish. Tucker et al. [97] showed that aspects of personality (e.g., activity and boldness) did not influence $\mathrm{CO}_{2}$ tolerance in bluegill, with fish of all personality types requiring similar durations of time to induce equilibrium loss when exposed to 123,000 $\mu \mathrm{atm}$. Hasler et al. [108] showed that tolerance to $\mathrm{CO}_{2}$ was influenced by the metabolic phenotype of largemouth bass, and fish with higher anaerobic performance, quantified as time to become exhausted when burst swimming, required less time to lose equilibrium when exposed to high $\mathrm{CO}_{2}$, and also that aerobic aspects of metabolic phenotype (i.e., standard metabolic rate, aerobic scope) did not influence tolerance to carbon dioxide. Suski et al. [101] showed that largemouth bass that had been deprived of food for 14 days required 25\% longer exposure to high $\mathrm{CO}_{2}$, relative to fish that had been fed over this 14 day period, thereby demonstrating an increased tolerance to $\mathrm{CO}_{2}$ from food deprivation. Together, tolerance to high $\mathrm{CO}_{2}$ can vary due to a number of endogenous and exogenous factors and should be considered should $\mathrm{CO}_{2}$ be deployed to deter the movement of invasive fishes (Table 3).

Table 3. Factors influencing the tolerance of $\mathrm{CO}_{2}$, indicated by loss of equilibrium.

\begin{tabular}{|c|c|c|c|c|}
\hline & Factor & Outcome & Species & Citation \\
\hline \multirow{4}{*}{$\begin{array}{l}\text { Factors resulting in a } \\
\text { higher threshold for } \\
\text { equilibrium loss in } \mathrm{CO}_{2}\end{array}$} & Size & $\begin{array}{l}\text { large fish lost equilibrium sooner } \\
\text { (were more sensitive) at a given } \mathrm{CO}_{2} \\
\text { concentration than small fish. }\end{array}$ & Rainbow trout & [81] \\
\hline & $\begin{array}{c}\text { Time } \times \text { concentration } \\
\text { interaction }\end{array}$ & $\begin{array}{l}\text { Equilibrium loss occurs at extended } \\
\text { exposure to low } \mathrm{CO}_{2} \text { concentration, } \\
\text { or brief exposure to high } \\
\mathrm{CO}_{2} \text { concentration. }\end{array}$ & $\begin{array}{l}\text { Several species of } \\
\text { salmonid } \\
\text { (steelhead, chinook) }\end{array}$ & {$[69,70]$} \\
\hline & Temperature & $\begin{array}{l}\text { When } \mathrm{CO}_{2} \text { was added to a tank at a } \\
\text { constant rate, a higher } \mathrm{CO}_{2} \\
\text { concentration was required to induce } \\
\text { equilibrium loss at high temperatures } \\
\text { relative to low temperatures. }\end{array}$ & $\begin{array}{l}\text { Silver carp, bighead } \\
\text { carp, round goby. }\end{array}$ & {$[104,105]$} \\
\hline & Food deprivation & $\begin{array}{l}\text { Fish that had been deprived food for } \\
14 \text { days required more } \mathrm{CO}_{2} \text { to induce } \\
\text { equilibrium loss than fed conspecifics. }\end{array}$ & Largemouth bass & [101] \\
\hline \multirow{2}{*}{$\begin{array}{l}\text { Factors resulting in a } \\
\text { lower threshold for } \\
\text { equilibrium loss in } \mathrm{CO}_{2}\end{array}$} & Temperature & $\begin{array}{l}\text { Equilibrium loss occurs faster at } \\
\text { higher temperature when } \mathrm{CO}_{2} \\
\text { concentration is held constant. }\end{array}$ & $\begin{array}{l}\text { Several species of } \\
\text { salmonid } \\
\text { (steelhead, chinook) }\end{array}$ & {$[69,110]$} \\
\hline & $\begin{array}{l}\text { Anaerobic swimming } \\
\text { potential }\end{array}$ & $\begin{array}{l}\text { Fish that required longer to become } \\
\text { exhausted during burst swimming } \\
\text { required less time to lose equilibrium } \\
\text { at high } \mathrm{CO}_{2} \text {. }\end{array}$ & Largemouth bass & [108] \\
\hline \multirow{3}{*}{$\begin{array}{l}\text { Factors not influencing } \\
\text { equilibrium loss in high } \\
\mathrm{CO}_{2} \text { environments }\end{array}$} & $\begin{array}{l}\text { Standard metabolic } \\
\text { rate }\end{array}$ & $\begin{array}{l}\text { Variation in standard metabolic rate } \\
\text { did not predict time to equilibrium } \\
\text { loss in high } \mathrm{CO}_{2} \text {. }\end{array}$ & Largemouth bass & [108] \\
\hline & Aerobic scope & $\begin{array}{l}\text { Variation in aerobic scope did not } \\
\text { predict time to equilibrium loss in } \\
\text { high } \mathrm{CO}_{2} \text {. }\end{array}$ & Largemouth bass & [108] \\
\hline & $\begin{array}{l}\text { Personality (activity, } \\
\text { boldness) }\end{array}$ & $\begin{array}{l}\text { Variation in activity and boldness did } \\
\text { not influence time to equilibrium loss } \\
\text { in high } \mathrm{CO}_{2} \text {. }\end{array}$ & Bluegill & [97] \\
\hline
\end{tabular}

\section{Management Implications}

There are a number of potential non-physical barriers that can be deployed to prevent the spread of invasive fishes, including bubble screens, sound or electricity, each with particular strengths and weaknesses [45]. A non-physical barrier that uses zones of elevated carbon dioxide to deter fish movements has a number an advantageous as a chemical control tool relative to other technologies as it has few human health concerns, can be applied in a carbon neutral fashion using repurposed $\mathrm{CO}_{2}$ (i.e., harvesting waste $\mathrm{CO}_{2}$ destined to be released into the atmosphere), is relatively inexpensive and readily available, can be deployed with relatively little infrastructure, and residual $\mathrm{CO}_{2}$ does not persist in the environment [113]. Carbon dioxide was recently registered with the United States Environmental 
Protection Agency (USEPA) as a pesticide for use as a deterrent of bigheaded carp under the name Carbon Dioxide-Carp (EPA Registration Number 6704-95). Dennis et al. [103] held largemouth bass at 21,000 $\mu \mathrm{atm}(13 \mathrm{mg} / \mathrm{L}) \mathrm{CO}_{2}$ for almost two months and showed no decline in avoidance thresholds, suggesting that acclimation to the presence of high $\mathrm{CO}_{2}$ is not likely. Most important, the avoidance response of fishes to environmental $\mathrm{CO}_{2}$ appears to be canalized, demonstrated by virtually all fish species tested, while $\mathrm{CO}_{2}$ tolerance is repeatable and consistent [108], giving $\mathrm{CO}_{2}$ a number of advantages as a non-physical fish barrier as a tool to deter invasive fishes.

Results from the studies listed above have a number of implications for the deployment of $\mathrm{CO}_{2}$ as a non-physical barrier and can be used to minimize the likelihood of unintentional fish passage, while also helping minimize waste $\mathrm{CO}_{2}$ and reduce deployment costs. For example, for a $\mathrm{CO}_{2}$ barrier deployed with the intention of causing avoidance, it is important for managers to consider the context in which the barrier is deployed. More specifically, although not repeatable within individuals, avoidance of $\mathrm{CO}_{2}$ has been shown to be consistent across virtually all species tested when $\mathrm{CO}_{2}$ pressures reach approximately 30,000-60,000 $\mu \mathrm{atm}(60-100 \mathrm{mg} / \mathrm{L})$. However, avoidance thresholds will likely be lower for fish in shoals (rather than individual fish) but will increase if fish are experiencing stress (independent of food availability), such as chronic hypoxia or environmental pollution. Finally, studies suggest that higher concentrations of $\mathrm{CO}_{2}$ may be required to induce avoidance at warmer water temperatures (summer) relative to cooler conditions (Table 2). It should be noted that Schneider et al. [114] showed that $\mathrm{CO}_{2}$ did not impair either the burst or sprint swimming performance of largemouth bass until thresholds of $100,000 \mu \mathrm{atm}$ were reached (approximately $150 \mathrm{mg} / \mathrm{L}$ ), well in excess of thresholds required to induce

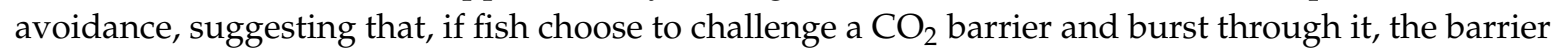
will likely not impair swimming performance. When considered together, a number of factors should be considered to ensure maximum effectiveness should $\mathrm{CO}_{2}$ be used in the field to deter the movement of invasive fishes (Table 2).

If a $\mathrm{CO}_{2}$ barrier is deployed with the intent of stopping fish via equilibrium loss (tolerance), aspects of individual fish need to be considered as these factors can influence effectiveness. At present, the relationship between exposure time $\times \mathrm{CO}_{2}$ concentrations that results in equilibrium loss for most species has not been defined, so these data would need to be collected to help guide management targets, and owing to individual variation in the loss of equilibrium time for fish [108], a large number of fish would need to be assessed to quantify a range of equilibrium loss times. In general, however, small fish, and individuals that had been deprived of food, would be expected to have improved tolerance in high $\mathrm{CO}_{2}$ relative to larger, well-fed individuals. The role of environmental temperature has not been clearly defined, but studies suggest that a longer exposure time may be required at lower water temperatures and in periods of low food availability (e.g., winter) (Table 3).

\section{Future Work}

At present, there are five areas that should be the focus of future studies to improve the performance and efficacy of $\mathrm{CO}_{2}$ as a non-physical barrier. Firstly, additional work should focus on defining differences in both avoidance and tolerance thresholds across fish of different sizes; this is particularly important given the possibility that electricity as a barrier may lose effectiveness against small fish [43]. Currently, work that quantifies avoidance and tolerance thresholds across a range of sizes of fishes, within a single study with consistent methods, has not occurred. Owing to the likelihood that a $\mathrm{CO}_{2}$ barrier would be encountered by fish of a range of sizes, the ability to confidently predict the response of different sized individuals to either a tolerance or avoidance application of $\mathrm{CO}_{2}$ is critical. Secondly, the exact parameters of the time $\times$ concentration interaction to induce equilibrium loss associated with a tolerance-focused barrier have not been defined extensively, and would need to be parameterized across target species before tolerance barriers could be developed and/or implemented. Ideally, this work would be conducted across a range of temperatures. Thirdly, work should be conducted that pairs $\mathrm{CO}_{2}$ barriers with additional stimuli (e.g., deploy a sound barrier and $\mathrm{CO}_{2}$ barrier concurrently as in Ruebush et al. [115], or use $\mathrm{CO}_{2}$ as part of a bubble curtain rather 
than compressed air). No non-physical barrier is $100 \%$ effective at stopping all fish [45], but a $\mathrm{CO}_{2}$ barrier paired with a second stimulus (e.g., light or sound barriers) could synergistically improve the overall effectiveness of each barrier, increasing the potential to deter invasive fishes across a range of conditions. Penultimately, efforts need to occur to quantify the logistics of $\mathrm{CO}_{2}$ deployment, including cost estimates, deployment feasibility and infrastructure requirements to assist with future planning efforts. The design for deploying a $\mathrm{CO}_{2}$ barrier will vary across sites and situations, but efforts to share costs and strategies across successful applications will help improve deployment efficiency and ensure success across locations. Finally, owing to the unavoidable reductions in $\mathrm{pH}$ that occur with zones of elevated $\mathrm{CO}_{2}$, work should continue to quantify the environmental impacts [116,117], consequences for non-target organisms (e.g., mussels [118,119]; native fishes [120-122]; crayfish [123]) and strategies for $\mathrm{CO}_{2}$ off-gassing. Work to both mitigate $\mathrm{CO}_{2}$ applications, coupled with efforts to predict possible impacts to non-target organisms or the receiving environment, will help improve the likelihood of a successful application. Together, work to address these 5 concerns will not only help improve the effectiveness of $\mathrm{CO}_{2}$ as a non-physical barrier, but also will help minimize unintended environmental consequences and improve the efficiency of $\mathrm{CO}_{2}$ as a tool to deter invasive fishes.

\section{Conclusions}

Invasive species represent a significant threat to global biodiversity, and models suggest that the rate of introduction of invasive species will likely accelerate in the future [16]. For fishes in North America, bigheaded carp represent a current threat to the Mississippi ecosystem, and there is potential for them to gain access to waterbodies in the eastern portion of the continent should they pass through the Chicago Area Waterway System (CAWS) into the Great Lakes basin. Carbon dioxide $\left(\mathrm{CO}_{2}\right)$ is a naturally occurring compound that provides ecologically-relevant information to a host of taxa. A number of different studies, conducted across a range of conditions, have demonstrated that zones of elevated carbon dioxide gas can be an effective non-physical barrier to deter the spread of invasive fishes. More specifically, fish will voluntarily swim away from zones of high $\mathrm{CO}_{2}$ once a target threshold has been reached, or else equilibrium loss will occur due to the anesthetic properties of $\mathrm{CO}_{2}$, providing two different mechanisms by which carbon dioxide can deter fish movement. This response has been documented for a number of taxonomically diverse species of fish, and also across a range of sizes spanning from larvae to adults. In addition, unlike physical barriers, a $\mathrm{CO}_{2}$ barrier can be deployed without requiring the construction of permanent structures that can modify water flow or boat traffic. Several internal and external factors can influence the response of fishes to $\mathrm{CO}_{2}$, making them more effective, or less effective (e.g., fish experiencing stress will require additional $\mathrm{CO}_{2}$ to induce avoidance relative to non-stressed individuals; shoals of fish require less $\mathrm{CO}_{2}$ to induce avoidance relative to solitary individuals) and need to be considered when defining target thresholds should $\mathrm{CO}_{2}$ be deployed in the field. Additional studies to define effective deployment strategies at large scales, cost, and impacts to the receiving environment should continue as $\mathrm{CO}_{2}$ barriers grow in popularity and field applications. Work is currently ongoing to develop other non-physical barriers to deter invasive fishes (e.g., sound, electricity, strobe lights), and the lessons learned and experiences described here from $\mathrm{CO}_{2}$ can serve as potential considerations to refine the application of other barrier technologies to increase their effectiveness. Together, with continued exploration and testing, it is hoped that barrier technologies can be further developed to prevent the spread of invasive fishes and protect freshwater biodiversity. 
Funding: This research was funded by the Illinois Department of Natural Resources, and the United States Geological Survey, through funds provided by the United States Environmental Protection Agency's Great Lakes Restoration Initiative.

Acknowledgments: A number of individuals have contributed to field and laboratory work that have generated the data contained in this review, including Caleb Hasler, Jennifer Jeffrey, Kelly Hannan, John Tix, Eric Schneider, Emi Tucker, Madison Philipp, Ian Bouyoucos, Christa Woodley, Cody Sullivan, Jason Romine, Dave Smith, Steve Midway, Aaron Cupp, Jon Amberg, Mark Gaikowski, Clark Dennis, Matt Noatch, Dan Kates, Shivani Adhikari, Michael Donaldson, and Adam Wright. Jake Wolf fish hatchery provided fish for experiments, and staff at the Illinois River Biological Station facilitated the collection of carp. Caleb Hasler provided comments on an early version of this review.

Conflicts of Interest: The author declares no conflict of interest.

\section{References}

1. Lodge, D.M.; Williams, S.; MacIsaac, H.J.; Hayes, K.R.; Leung, B.; Reichard, S.; Mack, R.N.; Moyle, P.B.; Smith, M.; Andow, D.A.; et al. Biological Invasions: Recommendations for US Policy and Management. Ecol. Appl. 2006, 16, 2035-2054. [CrossRef]

2. Britton, J.R.; Davies, G.D.; Harrod, C. Trophic Interactions and Consequent Impacts of the Invasive Fish Pseudorasbora Parva in a Native Aquatic Foodweb: A Field Investigation in the UK. Boil. Invasions 2009, 12, 1533-1542. [CrossRef]

3. Gozlan, R.E.; Britton, J.R.; Cowx, I.; Copp, G.H. Current Knowledge on Non-Native Freshwater Fish Introductions. J. Fish Boil. 2010, 76, 751-786. [CrossRef]

4. Wilcove, D.S.; Rothstein, D.; Dubow, J.; Phillips, A.; Losos, E. Quantifying Threats to Imperiled Species in the United States. BioScience 1998, 48, 607-615. [CrossRef]

5. Pimentel, D.; Zuniga, R.; Morrison, D. Update on the Environmental and Economic Costs Associated with Alien-Invasive Species in the United States. Ecol. Econ. 2005, 52, 273-288. [CrossRef]

6. Pejchar, L.; Mooney, H.A. Invasive Species, Ecosystem Services and Human Well-Being. Trends Ecol. Evol. 2009, 24, 497-504. [CrossRef]

7. Strayer, D.L.; Dudgeon, D. Freshwater Biodiversity Conservation: Recent Progress and Future Challenges. J. N. Am. Benthol. Soc. 2010, 29, 344-358. [CrossRef]

8. Wu, J. Landscape Sustainability Science: Ecosystem Services and Human Well-Being in Changing Landscapes. Landsc. Ecol. 2013, 28, 999-1023. [CrossRef]

9. Jenkins, M. Prospects for Biodiversity. Science 2003, 302, 1175-1177. [CrossRef]

10. Reid, A.J.; Carlson, A.K.; Creed, I.F.; Eliason, E.J.; Gell, P.A.; Johnson, P.T.J.; Kidd, K.A.; MacCormack, T.J.; Olden, J.D.; Ormerod, S.J.; et al. Emerging Threats and Persistent Conservation Challenges for Freshwater Biodiversity. Boil. Rev. 2018, 94, 849-873. [CrossRef]

11. Dudgeon, D.; Arthington, A.H.; Gessner, M.O.; Kawabata, Z.-I.; Knowler, D.J.; Lévêque, C.; Naiman, R.J.; Prieur-Richard, A.; Soto, D.; Stiassny, M.L.J.; et al. Freshwater Biodiversity: Importance, Threats, Status and Conservation Challenges. Boil. Rev. 2005, 81, 163-182. [CrossRef] [PubMed]

12. Jelks, H.L.; Walsh, S.J.; Burkhead, N.M.; Contreras-Balderas, S.; Díaz-Pardo, E.; Hendrickson, D.A.; Lyons, J.; Mandrak, N.E.; McCormick, F.; Nelson, J.S.; et al. Conservation Status of Imperiled North American Freshwater and Diadromous Fishes. Fisheries 2008, 33, 372-407. [CrossRef]

13. Burkhead, N.M. Extinction Rates in North American Freshwater Fishes, 1900-2010. BioScience 2012, 62, 798-808. [CrossRef]

14. Seebens, H.; Blackburn, T.M.; Dyer, E.E.; Genovesi, P.; Hulme, P.E.; Jeschke, J.M.; Pagad, S.; Pyšek, P.; Winter, M.; Arianoutsou, M.; et al. No Saturation in the Accumulation of Alien Species Worldwide. Nat. Commun. 2017, 8, 1-9. [CrossRef] [PubMed]

15. Chapin, F.S.; Zavaleta, E.S.; Eviner, V.T.; Naylor, R.L.; Vitousek, P.M.; Reynolds, H.L.; Hooper, D.U.; Lavorel, S.; Sala, O.E.; Hobbie, S.; et al. Consequences of Changing Biodiversity. Nature 2000, 405, 234-242. [CrossRef] [PubMed]

16. Sardain, A.; Sardain, E.; Leung, B. Global Forecasts of Shipping Traffic and Biological Invasions to 2050. Nat. Sustain. 2019, 2, 274-282. [CrossRef] 
17. Clout, M.N.; Veitch, C.R. Turning the tide of biological invasion: the potential for eradicating invasive species. In Turning the Tide: The Eradication of Invasive Species; IUCN SSC Invasive Species Specialist Group: Gland, Switzerland; Cambridge, UK, 2002; pp. 1-3. Available online: http://www.issg.org/pdf/publications/turning the_tide.pdf (accessed on 1 June 2020).

18. Simberloff, D. Eradication-Preventing Invasions at the Outset. Weed Sci. 2003, 51, 247-253. [CrossRef]

19. Simberloff, D. We can eliminate invasions or live with them. Successful management projects. In Ecological Impacts of Non-Native Invertebrates and Fungi on Terrestrial Ecosystems; Langor, D., Sweeney, J., Eds.; Springer: Dordrecht, The Netherlands, 2008; pp. 149-157, ISBN 978-1-4020-9680-8.

20. Simberloff, D. Eradication: Pipe dream or real option? In Plant Invasions in Protected Areas; Foxcroft, L.C., Pyšek, P., Richardson, D.M., Genovesi, P., Eds.; Springer: Dordrecht, The Netherlands, 2013; pp. 549-559, ISBN 978-94-007-7750-7.

21. Leung, B.; Lodge, D.M.; Finnoff, D.; Shogren, J.F.; Lewis, M.A.; Lamberti, G. An Ounce of Prevention or a Pound of Cure: Bioeconomic Risk Analysis of Invasive Species. Proc. R. Soc. B Boil. Sci. 2002, 269, $2407-2413$. [CrossRef]

22. Finnoff, D.; Shogren, J.F.; Leung, B.; Lodge, D. Take a Risk: Preferring Prevention over Control of Biological Invaders. Ecol. Econ. 2007, 62, 216-222. [CrossRef]

23. Zanden, M.J.V.; Olden, J.D. A Management Framework for Preventing the Secondary Spread of Aquatic Invasive Species. Can. J. Fish. Aquat. Sci. 2008, 65, 1512-1522. [CrossRef]

24. Kocovsky, P.M.; Chapman, D.C.; Qian, S. "Asian Carp" Is Societally and Scientifically Problematic. Let's Replace It. Fisheries 2018, 43, 311-316. [CrossRef]

25. Kolar, C.S.; Chapman, D.C.; Courtenay, W.R.J.; Housel, C.M.; Williams, J.D.; Jennings, D.P. Asian Carps of the Genus Hypophthalmichthys (Pisces, Cyprinidae)—A Biological Synopsis and Environmental Risk Assessment; American Fisheries Society Special Publication: Bethesda, MD, USA, 2007; Volume 33, ISBN 978-1-888569-79-7.

26. Whitledge, G.W.; Knights, B.; Vallazza, J.; Larson, J.; Weber, M.J.; Lamer, J.T.; Phelps, Q.E.; Norman, J.D. Identification of Bighead Carp and Silver Carp Early-Life Environments and Inferring Lock and Dam 19 Passage in the Upper Mississippi River: Insights from Otolith Chemistry. Boil. Invasions 2018, 21, 1007-1020. [CrossRef]

27. Sass, G.G.; Hinz, C.; Erickson, A.C.; McClelland, N.N.; McClelland, M.A.; Epifanio, J.M. Invasive Bighead and Silver Carp Effects on Zooplankton Communities in the Illinois River, Illinois, USA. J. Great Lakes Res. 2014, 40, 911-921. [CrossRef]

28. Kuznetsov, Y.A. Consumption of Bacteria by the Silver Carp (Hypophthalmichthys molitrix). J. Ichthyol. 1977, 17, 398-403.

29. Fukushima, M.; Takamura, N.; Sun, L.; Nakagawa, M.; Matsushige, K.; Xie, P. Changes in the Plankton Community Following Introduction of Filter-Feeding Planktivorous Fish. Freshw. Boil. 1999, 42, 719-735. [CrossRef]

30. Laws, E.A.; Weisburd, R. Use of Silver Carp to Control Algal Biomass in Aquaculture Ponds. Progress. Fish-Culturist 1990, 52, 1-8. [CrossRef]

31. Lieberman, D.M. Use of Silver Carp (Hypophthalmichthys molotrix) and Bighead Carp (Aristichthys nobilis) for Algae Control in a Small Pond: Changes in Water Quality. J. Freshw. Ecol. 1996, 11, 391-397. [CrossRef]

32. Irons, K.S.; Sass, G.G.; McClelland, M.A.; Stafford, J.D. Reduced Condition Factor of Two Native Fish Species Coincident with Invasion of Non-Native Asian Carps in the Illinois River, USA Is This Evidence for Competition and Reduced Fitness? J. Fish Boil. 2007, 71, 258-273. [CrossRef]

33. Pendleton, R.M.; Schwinghamer, C.; Solomon, L.E.; Casper, A.F. Competition among River Planktivores: Are Native Planktivores Still Fewer and Skinnier in Response to the Silver Carp Invasion? Environ. Boil. Fishes 2017, 100, 1213-1222. [CrossRef]

34. Chick, J.H.; Gibson-Reinemer, D.K.; Soeken-Gittinger, L.; Casper, A.F. Invasive Silver Carp is Empirically Linked to Declines of Native Sport Fish in the Upper Mississippi River System. Boil. Invasions 2019, 22, 723-734. [CrossRef]

35. Asian Carp Regional Coordinating Committee. Asian Carp Monitoring and Response Plan. 2018. Available online: https://www.asiancarp.us/Documents/MRP2018.pdf (accessed on 1 June 2020).

36. Hill, L. The Chicago River: A Natural and Unnatural History; Lake Claremont Press: Chicago, IL, USA, 2000. 
37. Moy, P.B.; Polls, I.; Dettmers, J.M. The Chicago Sanitary and Ship Canal aquatic nuisance species dispersal barrier. In Invasive Asian Carps in North America, American Fisheries Society Symposium; Chapman, D.C., Hoff, M.H., Eds.; American Fisheries Society: Bethesda, MD, USA, 2010; Volume 74, pp. 121-137.

38. Rasmussen, J.L.; Regier, H.A.; Sparks, R.E.; Taylor, W.W. Dividing the Waters: The Case for Hydrologic Separation of the North American Great Lakes and Mississippi River Basins. J. Great Lakes Res. 2011, 37, 588-592. [CrossRef]

39. Asian Carp Regional Coordinating Committee. Asian Carp Action Plan. 2020. Available online: https: //www.asiancarp.us/Documents/2020-Action-Plan.pdf (accessed on 1 June 2020).

40. Dettmers, J.M.; Boisvert, B.A.; Barkley, T.; Sparks, R.E. Potential Impact of Steel-Hulled Barges on Movement of Fish across an Electric Barrier to Prevent the Entry of Invasive Carp into Lake Michigan; Aquatic Ecology Technical Report 2005/19; Illinois Natural History Survey Center for Aquatic Ecology: Zion, IL, USA, 2005; Available online: https://www.ideals.illinois.edu/bitstream/handle/2142/10091/inhscaev02005i00019_opt.pdf? sequence $=2 \&$ is Allowed $=y$ (accessed on 1 June 2020).

41. Sparks, R.E.; Barkley, T.L.; Creque, S.M.; Dettmers, J.M.; Stainbrook, K.M. Evaluation of an electric fish dispersal barrier in the Chicago Sanitary and Ship Canal. In Invasive Asian Carps in North America, American Fisheries Society Symposium; Chapman, D.C., Hoff, M.H., Eds.; American Fisheries Society: Bethesda, MD, USA, 2010; Volume 74, pp. 139-161.

42. Evans, N.T.; Brouder, M.J. Asian Carp Entrainment, Retainment and Upstream Transport by Commercial Barge tows on the Illinois Waterway -2018 Trials; US Fish \& Wildlife Service Report; US Fish and Wildlife Service Carterville Fish and Wildlife Conservation Office: Willmington, IL, USA, 2020. Available online: https://www. fws.gov/midwest/fisheries/carterville/documents/2018-Barge-Entrainment-Study-Report.pdf (accessed on 1 June 2020).

43. Parker, A.D.; Rogers, P.B.; Finney, S.T.; Simmonds, R.L.J. Preliminary Results of Fixed DIDSON Evaluations at the Electric Dispersal Barrier in the Chicago Sanitary and Ship Canal; US Fish \& Wildlife Service Report; US Fish and Wildlife Service, Carterville Fish and Wildlife Conservation Office: Willmington, IL, USA, 2013. Available online: https://www.fws.gov/midwest/fisheries/carterville/documents/DIDSON.pdf (accessed on 1 June 2020).

44. Reynolds, J.B. Electrofishing. In Fisheries Techniques, 2nd ed.; Murphy, B.R., Willis, D.W., Eds.; American Fisheries Society: Bethesda, MD, USA, 1996; pp. 221-253, ISBN 9781888569001.

45. Noatch, M.R.; Suski, C.D. Non-Physical Barriers to Deter Fish Movements. Environ. Rev. 2012, 20, 71-82. [CrossRef]

46. USACE. The Great Lakes and Mississippi River Interbasin Study_Brandon Road Final Integrated Feasibility Study and Environmental Impact Statement-Will County, Illinois; US Army Corps of Engineers, Rock Island and Chicago Districts: Rock Island, TN, USA; Chicago, IL, USA, 2018; Available online: https://usace.contentdm. oclc.org/utils/getfile/collection/p16021coll7/id/11394 (accessed on 1 June 2020).

47. Cooke, S.; Hill, W.R. Can Filter-Feeding Asian Carp Invade the Laurentian Great Lakes? A Bioenergetic Modelling Exercise. Freshw. Boil. 2010, 55, 2138-2152. [CrossRef]

48. Cuddington, K.; Currie, W.J.S.; Koops, M.A. Could an Asian Carp Population Establish in the Great Lakes from a Small Introduction? Boil. Invasions 2013, 16, 903-917. [CrossRef]

49. Wittmann, M.E.; Cooke, R.M.; Rothlisberger, J.D.; Rutherford, E.S.; Zhang, H.; Mason, D.M.; Lodge, D.M. Use of Structured Expert Judgment to Forecast Invasions by Bighead and Silver Carp in Lake Erie. Conserv. Boil. 2014, 29, 187-197. [CrossRef] [PubMed]

50. Lauber, T.B.; Stedman, R.C.; Connelly, N.A.; Rudstam, L.G.; Ready, R.C.; Poe, G.L.; Bunnell, D.B.; Höök, T.O.; Koops, M.A.; Ludsin, S.A.; et al. Using Scenarios to Assess Possible Future Impacts of Invasive Species in the Laurentian Great Lakes. N. Am. J. Fish. Manag. 2016, 36, 1292-1307. [CrossRef]

51. Zhang, H.; Rutherford, E.S.; Mason, D.M.; Breck, J.T.; Wittmann, M.E.; Cooke, R.M.; Lodge, D.M.; Rothlisberger, J.D.; Zhu, X.; Johnson, T.B. Forecasting the Impacts of Silver and Bighead Carp on the Lake Erie Food Web. Trans. Am. Fish. Soc. 2015, 145, 136-162. [CrossRef]

52. Cummins, E.P.; Strowitzki, M.J.; Taylor, C.T. Mechanisms and Consequences of Oxygen and Carbon Dioxide Sensing in Mammals. Physiol. Rev. 2020, 100, 463-488. [CrossRef]

53. Cummins, E.P.; Selfridge, A.C.; Sporn, P.H.S.; Sznajder, J.I.; Taylor, C.T. Carbon Dioxide-Sensing in Organisms and Its Implications for Human Disease. Cell. Mol. Life Sci. 2013, 71, 831-845. [CrossRef] 
54. Thom, C.; Guerenstein, P.G.; Mechaber, W.L.; Hildebrand, J.G. Floral $\mathrm{CO}_{2}$ Reveals Flower Profitability to Moths. J. Chem. Ecol. 2004, 30, 1285-1288. [CrossRef]

55. Seeley, T.D. Atmospheric Carbon Dioxide Regulation in Honey-Bee (Apis mellifera) Colonies. J. Insect Physiol. 1974, 20, 2301-2305. [CrossRef]

56. Gillies, M.T. The Role of Carbon Dioxide in Host-Finding by Mosquitoes (Diptera: Culicidae): A Review. Bull. Entomol. Res. 1980, 70, 525-532. [CrossRef]

57. Takken, W.; Knols, B.G.J. Odor-Mediated Behavior of Afrotropical Malaria Mosquitoes. Annu. Rev. Entomol. 1999, 44, 131-157. [CrossRef] [PubMed]

58. Faucher, C. Behavioral Responses of Drosophila to Biogenic Levels of Carbon Dioxide Depend on Life-Stage, Sex and Olfactory Context. J. Exp. Boil. 2006, 209, 2739-2748. [CrossRef]

59. Lahiri, S.; Forster II, R.E. $\mathrm{CO}_{2} / \mathrm{H}^{+}$Sensing: Peripheral and Central Chemoreception. Int. J. Biochem. Cell Biol. 2003, 35, 1413-1435. [CrossRef]

60. Shusterman, D. Individual Factors in Nasal Chemesthesis. Chem. Senses 2002, 27, 551-564. [CrossRef]

61. Tresguerres, M.; Milsom, W.K.; Perry, S.F. $\mathrm{CO}_{2}$ and acid-base sensing. In Carbon Dioxide; Farrell, A.P., Brauner, C.J., Eds.; Elsevier: San Diego, CA, USA, 2019; Volume 37, pp. 33-68, ISBN 9780128176108.

62. Eddy, F.B.; Lomholt, J.P.; Weber, R.E.; Johansen, K. Blood Respiratory Properties of Rainbow Trout (Salmo gairdneri) Kept in Water of High $\mathrm{CO}_{2}$ Tension. J. Exp. Boil. 1977, 67, 37-47.

63. Brauner, C.J.; Baker, D.W. Patterns of acid-base regulation during exposure to hypercarbia in fishes. In Cardio-Respiratory Control in Vertebrates; Glass, M.L., Wood, S.C., Eds.; Springer: Berlin/Heidelberg, Germany, 2009; pp. 43-63, ISBN 978-3-540-93984-9.

64. Bernier, N.J.; Randall, D.J. Carbon Dioxide Anaesthesia in Rainbow Trout: Effects of Hypercapnic Level and Stress on Induction and Recovery from Anaesthetic Treatment. J. Fish Biol. 1998, 52, 621-637.

65. Dennis, C.E.; Kates, D.F.; Noatch, M.R.; Suski, C.D. Molecular Responses of Fishes to Elevated Carbon Dioxide. Comp. Biochem. Physiol. Part A Mol. Integr. Physiol. 2015, 187, 224-231. [CrossRef]

66. Kates, D.; Dennis, C.; Noatch, M.R.; Suski, C.D. Responses of Native and Invasive Fishes to Carbon Dioxide: Potential for a Nonphysical Barrier to Fish Dispersal. Can. J. Fish. Aquat. Sci. 2012, 69, 1748-1759. [CrossRef]

67. Iwama, G.K.; McGeer, J.C.; Pawluk, M.P. The Effects of Five Fish Anaesthetics on Acid-Base Balance, Hematocrit, Blood Gases, Cortisol, and Adrenaline in Rainbow Trout. Can. J. Zool. 1989, 67, 2065-2073. [CrossRef]

68. Brauner, C.J.; Seidelin, M.; Madsen, S.S.; Jensen, F.B. Effects of Freshwater Hyperoxia and Hypercapnia and Their Influences on Subsequent Seawater Transfer in Atlantic Salmon (Salmo salar) Smolts. Can. J. Fish. Aquat. Sci. 2000, 57, 2054-2064. [CrossRef]

69. Fish, F.F. The Anaesthesia of Fish by High Carbon-Dioxide Concentrations. Trans. Am. Fish. Soc. 1943, 72, 25-29. [CrossRef]

70. Post, G. Carbonic Acid Anesthesia for Aquatic Organisms. Progress. Fish-Culturist 1979, 41, 142-144. [CrossRef]

71. Yoshikawa, H.; Yokoyama, Y.; Ueno, S.; Mitsuda, H. Changes of Blood Gas in Carp, Cyprinus Carpio, Anesthetized with Carbon Dioxide. Comp. Biochem. Physiol. Part A Physiol. 1991, 98, 431-436. [CrossRef]

72. Yoshikawa, H.; Kawai, F.; Kanamori, M. The Relationship between the EEG and Brain pH in Carp, Cyprinus carpio, Subjected to Environmental Hypercapnia at an Anesthetic Level. Comp. Biochem. Physiol. A Physiol. 1994, 107, 307-312.

73. Beitinger, T.L. Behavioral Reactions for the Assessment of Stress in Fishes. J. Great Lakes Res. 1990, 16, 495-528. [CrossRef]

74. Tierney, K.B. Chemical Avoidance Responses of Fishes. Aquat. Toxicol. 2016, 174, 228-241. [CrossRef]

75. Shelford, V.E.; Allee, W.C. The Reactions of Fishes to Gradients of Dissolved Atmospheric Gases. J. Exp. Zool. 1913, 14, 207-266. [CrossRef]

76. Powers, E.B.; Clark, R.T. Further Evidence on Chemical Factors Affecting the Migratory Movements of Fishes, Especially the Salmon. Ecology 1943, 24, 109-113. [CrossRef]

77. Collins, B.G. Factors Influencing the Orientation of Migrating Anadromous Fishes. Fish. Bull. 1952, 52, 375-396.

78. Bishai, H.M. Reactions of Larval and Young Salmonids to Different Hydrogen Ion Concentrations. ICES J. Mar. Sci. 1962, 27, 181-191. [CrossRef]

79. Jones, K.A.; Hara, T.J.; Scherer, E. Locomotor Response by Arctic Char (Salvelinus alpinus) to Gradients of $\mathrm{H}^{+}$ and $\mathrm{CO}_{2}$. Physiol. Zool. 1985, 58, 413-420. [CrossRef] 
80. Ross, R.M.; Krise, W.F.; Redell, L.A.; Bennett, R.M. Effects of Dissolved Carbon Dioxide on the Physiology and Behavior of Fish in Artificial Streams. Environ. Toxicol. 2001, 16, 84-95. [CrossRef]

81. Clingerman, J.; Bebak, J.; Mazik, P.M.; Summerfelt, S.T. Use of Avoidance Response by Rainbow Trout to Carbon Dioxide for Fish Self-Transfer between Tanks. Aquac. Eng. 2007, 37, 234-251. [CrossRef]

82. Yoshikawa, H.; Ishida, Y.; Ueno, S.; Mitsuda, H. Anesthetic Effect of $\mathrm{CO}_{2}$ on Fish. I. Changes in Depth of Anesthesia of the Carp Anesthetized with a Constant Level of $\mathrm{CO}_{2}$. Nippon. Suisan Gakkaishi 1988, 54, 457-462. [CrossRef]

83. Pirhonen, J.; Schreck, C.B. Effects of Anaesthesia with MS-222, Clove Oil and $\mathrm{CO}_{2}$ on Feed Intake and Plasma Cortisol in Steelhead Trout (Oncorhynchus mykiss). Aquaculture 2003, 220, 507-514. [CrossRef]

84. Dennis, C.E.; Adhikari, S.; Suski, C.D. Molecular and Behavioral Responses of Early-Life Stage Fishes to Elevated Carbon Dioxide. Boil. Invasions 2015, 17, 3133-3151. [CrossRef]

85. Summerfelt, R.C.; Lewis, W.M. Repulsion of Green Sunfish by Certain Chemicals. J. Water Pollut. Control. Fed. 1967, 39, 2030-2038.

86. Donaldson, M.R.; Amberg, J.; Adhikari, S.; Cupp, A.R.; Jensen, N.; Romine, J.; Wright, A.; Gaikowski, M.P.; Suski, C.D. Carbon Dioxide as a Tool to Deter the Movement of Invasive Bigheaded Carps. Trans. Am. Fish. Soc. 2016, 145, 657-670. [CrossRef]

87. Cupp, A.R.; Erickson, R.; Fredricks, K.T.; Swyers, N.M.; Hatton, T.W.; Amberg, J.J. Responses of Invasive Silver and Bighead Carp to a Carbon Dioxide Barrier in Outdoor Ponds. Can. J. Fish. Aquat. Sci. 2017, 74, 297-305. [CrossRef]

88. Cupp, A.R.; Smerud, J.; Tix, J.; Schleis, S.; Fredricks, K.; Erickson, R.A.; Amberg, J.; Morrow, W.; Koebel, C.; Murphy, E.; et al. Field Evaluation of Carbon Dioxide as a Fish Deterrent at a Water Management Structure along the Illinois River. Manag. Boil. Invasions 2018, 9, 299-308. [CrossRef]

89. Hasler, C.T.; Woodley, C.M.; Schneider, E.V.; Hixson, B.K.; Fowler, C.J.; Midway, S.R.; Suski, C.D.; Smith, D.L. Avoidance of Carbon Dioxide in Flowing Water by Bighead Carp. Can. J. Fish. Aquat. Sci. 2019, 76, 961-969. [CrossRef]

90. Sampson, S.J.; Chick, J.H.; Pegg, M.A. Diet Overlap among Two Asian Carp and Three Native Fishes in Backwater Lakes on the Illinois and Mississippi Rivers. Boil. Invasions 2008, 11, 483-496. [CrossRef]

91. Deters, J.E.; Chapman, D.C.; McElroy, B. Location and Timing of Asian Carp spawning in the Lower Missouri River. Environ. Boil. Fishes 2012, 96, 617-629. [CrossRef]

92. Réale, D.; Garant, D.; Humphries, M.M.; Bergeron, P.; Careau, V.; Montiglio, P.-O. Personality and the Emergence of the Pace-Of-Life Syndrome Concept at the Population Level. Philos. Trans. R. Soc. B Boil. Sci. 2010, 365, 4051-4063. [CrossRef]

93. Myles-Gonzalez, E.; Burness, G.; Yavno, S.; Rooke, A.C.; Fox, M.G. To Boldly Go Where No Goby Has Gone Before: Boldness, Dispersal Tendency, and Metabolism at the Invasion Front. Behav. Ecol. 2015, 26, 1083-1090. [CrossRef]

94. Cockrem, J.F. Stress, Corticosterone Responses and Avian Personalities. J. Ornithol. 2007, 148, 169-178. [CrossRef]

95. Koolhaas, J.; Korte, S.M.; De Boer, S.; Van Der Vegt, B.; Van Reenen, C.; Hopster, H.; De Jong, I.; Ruis, M.; Blokhuis, H. Coping Styles in Animals: Current Status in Behavior and Stress-Physiology. Neurosci. Biobehav. Rev. 1999, 23, 925-935. [CrossRef]

96. Réale, D.; Reader, S.M.; Sol, D.; McDougall, P.T.; Dingemanse, N.J. Integrating Animal Temperament within Ecology and Evolution. Boil. Rev. 2007, 82, 291-318. [CrossRef]

97. Tucker, E.K.; Suski, C.D.; Philipp, M.A.; Jeffrey, J.D.; Hasler, C.T. Glucocorticoid and Behavioral Variation in Relation to Carbon Dioxide Avoidance across Two Experiments in Freshwater Teleost Fishes. Boil. Invasions 2018, 21, 505-517. [CrossRef]

98. Tucker, E.K.; Suski, C.D. Presence of Conspecifics Reduces Between-Individual Variation and Increases Avoidance of Multiple Stressors in Bluegill. Anim. Behav. 2019, 158, 15-24. [CrossRef]

99. Killen, S.S.; Marras, S.; Metcalfe, N.B.; McKenzie, D.J.; Domenici, P. Environmental Stressors Alter Relationships between Physiology and Behaviour. Trends Ecol. Evol. 2013, 28, 651-658. [CrossRef] [PubMed]

100. Metcalfe, N.B.; Van Leeuwen, T.E.; Killen, S.S. Does Individual Variation in Metabolic Phenotype Predict Fish Behaviour and Performance? J. Fish Boil. 2015, 88, 298-321. [CrossRef] [PubMed]

101. Suski, C.D.; Philipp, M.A.; Hasler, C.T. Influence of Nutritional Status on Carbon Dioxide Tolerance and Avoidance Behavior in a Freshwater Teleost. Trans. Am. Fish. Soc. 2019, 148, 914-925. [CrossRef] 
102. Nadler, L.E.; Killen, S.S.; McClure, E.C.; Munday, P.L.; McCormick, M.I. Shoaling Reduces Metabolic Rate in a Gregarious Coral Reef Fish Species. J. Exp. Boil. 2016, 219, 2802-2805. [CrossRef] [PubMed]

103. Dennis, C.E.; Adhikari, S.; Wright, A.W.; Suski, C.D.; Dennis, C.E. Molecular, Behavioral, and Performance Responses of Juvenile Largemouth Bass Acclimated to an Elevated Carbon Dioxide Environment. J. Comp. Physiol. B 2016, 186, 297-311. [CrossRef]

104. Cupp, A.R.; Tix, J.; Smerud, J.; Erickson, R.A.; Fredricks, K.; Amberg, J.; Suski, C.D.; Wakeman, R. Using Dissolved Carbon Dioxide to Alter the Behavior of Invasive round Goby. Manag. Boil. Invasions 2017, 8, 567-574. [CrossRef]

105. Tix, J.A.; Cupp, A.R.; Smerud, J.R.; Erickson, R.; Fredricks, K.T.; Amberg, J.J.; Suski, C.D. Temperature Dependent Effects of Carbon Dioxide on Avoidance Behaviors in Bigheaded Carps. Boil. Invasions 2018, 20, 3095-3105. [CrossRef]

106. Beitinger, T.L.; Lutterschmidt, W.I. Measures of thermal tolerance. In Encyclopedia of Fish Physiology, 1st ed.; Farrell, A.P., Ed.; Elsevier: Waltham, MA, USA, 2011; pp. 1695-1702, ISBN 9780080923239.

107. Somero, G. Temporal Patterning of Thermal Acclimation: From Behavior to Membrane Biophysics. J. Exp. Boil. 2015, 218, 167-169. [CrossRef]

108. Hasler, C.T.; Bouyoucos, I.A.; Suski, C.D. Tolerance to Hypercarbia Is Repeatable and Related to a Component of the Metabolic Phenotype in a Freshwater Fish. Physiol. Biochem. Zool. 2017, 90, 583-587. [CrossRef] [PubMed]

109. Killen, S.S.; Adriaenssens, B.; Marras, S.; Claireaux, G.; Cooke, S.J. Context Dependency of Trait Repeatability and Its Relevance for Management and Conservation of Fish Populations. Conserv. Physiol. 2016, 4, cow007. [CrossRef] [PubMed]

110. Gelwicks, K.R.; Zafft, D.J.; Bobbitt, J.P. Efficacy of Carbonic Acid as an Anesthetic for Rainbow Trout. N. Am. J. Fish. Manag. 1998, 18, 432-438. [CrossRef]

111. Fivelstad, S.; Waagbø, R.; Stefansson, S.; Olsen, A.B. Impacts of Elevated Water Carbon Dioxide Partial Pressure at Two Temperatures on Atlantic Salmon (Salmo salar L.) Parr Growth and Haematology. Aquaculture 2007, 269, 241-249. [CrossRef]

112. Neiffer, D.L.; Stamper, M.A. Fish Sedation, Anesthesia, Analgesia, and Euthanasia: Considerations, Methods, and Types of Drugs. ILAR J. 2009, 50, 343-360. [CrossRef]

113. Fredricks, K.T.; Hubert, T.D.; Amberg, J.J.; Cupp, A.R.; Dawson, V.K. Chemical Controls for an Integrated Pest Management Program. N. Am. J. Fish. Manag. 2019. Available online: https://afspubs.onlinelibrary. wiley.com/doi/abs/10.1002/nafm.10339 (accessed on 2 June 2020). [CrossRef]

114. Schneider, E.V.; Hasler, C.T.; Suski, C.D. Swimming Performance of a Freshwater Fish during Exposure to High Carbon Dioxide. Environ. Sci. Pollut. Res. 2018, 26, 3447-3454. [CrossRef]

115. Ruebush, B.; Sass, G.; Chick, J.; Stafford, J. In-Situ Tests of Sound-Bubble-Strobe Light Barrier Technologies to Prevent Range Expansions of Asian Carp. Aquat. Invasions 2012, 7, 37-48. [CrossRef]

116. Hasler, C.T.; Midway, S.R.; Jeffrey, J.D.; Tix, J.A.; Sullivan, C.; Suski, C.D. Exposure to Elevated $p \mathrm{CO}_{2} \mathrm{Alters}$ Post-Treatment Diel Movement Patterns of Largemouth Bass over Short Time Scales. Freshw. Boil. 2016, 61, 1590-1600. [CrossRef]

117. Hasler, C.T.; Jeffrey, J.D.; Butman, D.; Suski, C. Freshwater Biota and Rising $p \mathrm{CO}_{2}$ ? Ecol. Lett. 2016, 19, 98-108. [CrossRef]

118. Jeffrey, J.D.; Hannan, K.D.; Hasler, C.T.; Suski, C.D. Hot and Bothered: Effects of Elevated $p \mathrm{CO}_{2}$ and Temperature on Juvenile Freshwater Mussels. Am. J. Physiol. Integr. Comp. Physiol. 2018, 315, R115-R127. [CrossRef] [PubMed]

119. Hannan, K.D.; Jeffrey, J.D.; Hasler, C.T.; Suski, C.D. Physiological Responses of Three Species of Unionid Mussels to Intermittent Exposure to Elevated Carbon Dioxide. Conserv. Physiol. 2016, 4, cow066. [CrossRef] [PubMed]

120. Hasler, C.T.; Jeffrey, J.D.; Schneider, E.V.; Hannan, K.D.; Tix, J.A.; Suski, C.D. Biological Consequences of Weak Acidification Caused by Elevated Carbon Dioxide in Freshwater Ecosystems. Hydrobiologia 2017, 806, 1-12. [CrossRef]

121. Midway, S.R.; Hasler, C.T.; Wagner, T.; Suski, C.D. Predation of Freshwater Fish in Elevated Carbon Dioxide Environments. Mar. Freshwater Res. 2017, 68, 1585-1592. [CrossRef] 
122. Tix, J.A.; Hasler, C.T.; Sullivan, C.; Jeffrey, J.D.; Suski, C.D. Elevated Carbon Dioxide Has the Potential to Impact Alarm Cue Responses in Some Freshwater Fishes. Aquat. Ecol. 2016, 51, 59-72. [CrossRef]

123. Robertson, M.; Hernandez, M.F.; Midway, S.R.; Hasler, C.T.; Suski, C.D. Shelter-Seeking Behavior of Crayfish, Procambarus Clarkii, in Elevated Carbon Dioxide. Aquat. Ecol. 2018, 52, 225-233. [CrossRef]

(C) 2020 by the author. Licensee MDPI, Basel, Switzerland. This article is an open access article distributed under the terms and conditions of the Creative Commons Attribution (CC BY) license (http://creativecommons.org/licenses/by/4.0/). 